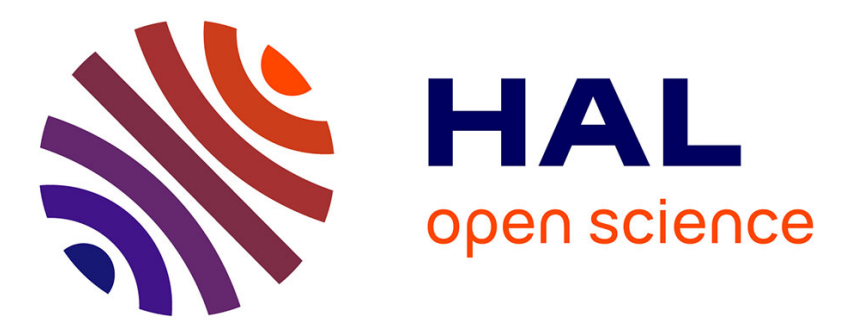

\title{
Savanna fire regimes assessment with MODIS fire data: their relationship to land cover and plant species distribution in western Burkina Faso (West Africa)
}

\author{
Jean-Louis Devineau, Anne Fournier, Saïbou Nignan
}

\section{- To cite this version:}

Jean-Louis Devineau, Anne Fournier, Saïbou Nignan. Savanna fire regimes assessment with MODIS fire data: their relationship to land cover and plant species distribution in western Burkina Faso (West Africa). Journal of Arid Environments, 2010, 74 (9), pp.1092-1101. 10.1016/j.jaridenv.2010.03.009 . hal-00369244

\section{HAL Id: hal-00369244 \\ https://hal.science/hal-00369244}

Submitted on 18 Mar 2009

HAL is a multi-disciplinary open access archive for the deposit and dissemination of scientific research documents, whether they are published or not. The documents may come from teaching and research institutions in France or abroad, or from public or private research centers.
L'archive ouverte pluridisciplinaire HAL, est destinée au dépôt et à la diffusion de documents scientifiques de niveau recherche, publiés ou non, émanant des établissements d'enseignement et de recherche français ou étrangers, des laboratoires publics ou privés. 


\section{Savanna fire regimes assessment with MODIS fire data: their relationship to land cover and plant species distribution in western Burkina Faso (West Africa).}

Devineau JL, Fournier A, Nignan S.

Original version before submission

\section{Summary}

The West African savannas are subject to changes in fire regimes related to land use intensification, which may infer significant biological modifications. We investigated the efficiency of MODIS fire products to account for the variability of fire regimes in relation to changes in land cover and savanna vegetation. The specificity and complementarities of both MODIS active fire (MOD14A2 and MYD14A2) and burned area (MCD45A1) products were assessed in order to characterize fire regimes and to relate them with land cover. In addition the distribution of plant species between landscape units characterized by specific fire regimes was assessed. The calculation of the mutual information made it possible to set apart species more frequent in landscapes little or not at all subject to fires and species more frequent in burnt areas. The first group is the expression of the nature of the unburnt land-cover units, mainly constituted by the agricultural areas dominated by fields and fallows. It consists of more potential threats (weeds, encroachers, invasive species etc.) than the second group, which is more typical of sudanian savannas. It thus appears that unburnt landscape units are currently more sensitive and vulnerable to some biological threats than the burned savannas, where fire provides the long-term stability needed to preserve the ecosystem.

\section{Introduction}

Fire is a main determinant of the West African savannas, thus changes in fire regimes, i.e. the intensity and frequency of fire, may infer significant biological modifications (Menaut \& César 1982, Gillon 1983, Frost \& Robertson 1987, Louppe et al. 1995a \& b, Getzin 2002, Govender et al. 2006, Nielsen et al. 2003). Severe changes in vegetation types and in floristic composition can indeed be expected, as demonstrated by various investigations made in different fire- prone vegetation worldwide (Aubréville 1953, Goldammer \& Price 1998, Hoffman 1999, Moreira 2000, Wheaton 2001, Williams et al. 2002, Whitlock et al. 2003, 
Backer et al. 2004, Dellasala et al. 2004, McKenzie et al. 2004, Bond et al. 2005, Doe 2008, Moretti et al. 2008, Pausas et al. 2008, Roitman et al. 2008). Such changes can have social and economic consequences, notably because of the importance of pastoral and wild resources for the sudanian rural societies. Fire regimes may therefore reveal land cover patterns and related land uses (Dolidon 2005, 2007); detecting spatial or temporal changes in fire regimes can then help to detect underlying environmental changes (Morgan et al. 2001, Kasischke \& Turetsky 2006).

The assessment of fire regimes across broad territories is carried out efficiently by means of data obtained by remote sensing (Kerr \& Ostrovsky 2003, Mayaux et al. 2003, Lentile et al. 2006, Chuvieco et al. 2008) such as MODIS fire data, that are specifically designed for this purpose (Justice et al. 2006). The MODIS products are currently downloadable free of charge and can thus be very generally used. Many studies highlighted potentialities and limitations of the MODIS active fire product (De Klerk 2008), which maps fires detected four times a day when the satellites pass overhead (Justice et al. 2002). For MODIS burnt area products (which maps the spatial extent of recent fires), of which only a provisional version is available up to now for evaluation purposes, such studies are however few (Giglio 2005, Giglio et al. 2005, Roy et al. 2005, Roy et al. 2008). The results provided by the two products may diverge for some areas, but they also may be complementary (Roy et al. 2008). Therefore, ascertaining the accuracy of MODIS fire data in relation to various local conditions is currently required (Giglio et al. 2009).

In the savanna biome, fire regimes are closely related to the amount of standing herbaceous phytomass that varies in quantity and composition over space and time according to topography, land use, herbivores pressure and climatic variability (Mbow et al. 2000, Mbow et al. 2003, Van Langevelde et al. 2003, Hennenberg et al. 2006). Changes in land use and climatic variability are likely to change the fire regimes that modify the effects of fire on ecosystems; in particular this may alter the balance among taxa according to their fire tolerance. In fire- adapted ecosystems plant life histories appear fine-tuned to particular fire regimes linked to specific sites (Glover 1968, Moreira 2000, Bond et al. 2005 Keeley \& Bond 2001).

In the West African sudanian zone, the contrast between the pyrophytic flora of savannas and a former endemic flora of dry forests, still persisting in some place free of fire, was often reported (Aubréville 1947, 1949, Devineau 1984, 2001, Swaine 1992, Neumann \& MüllerHaude 1999). The capacity of some of these so-called dry forest species to colonize unburnt areas had also been demonstrated, so that some wooded areas may be recent (Larrue 2002). In 
addition the removal or alleviation of fire may favour the establishment of exogenic and wideranging species (D'Antonio \& Vitousek 1992). For example, in the zone studied these latter species are more abundant in the agricultural areas, which can result from, among other possible causes, a reduction in the activity of fires (Devineau et al. 2009). Up to what point such a disappearance of fire or such a reduction of the associated constraints can allow this dry forest (endemic) flora or, on the contrary, an exogenic flora of wide- ranging species to substitute for the savanna flora can therefore be questioned. The interrelations between savanna fire regimes and vegetation dynamics are indeed complex; they are constrained by various climatic, biotic and anthropogenic factors involving various feedbacks (Scholes, \& Archer 1997, Hoffmann et al. 2002, Van Langevelde et al. 2003, Beerling \& Osborne 2006,) and they are still not well understood either in their ecological or in their human aspects (Laris 2002, Wiegand et al. 2006).

This study aims at evaluating how fire regimes — characterized from the MODIS fire data are related to land-cover variability and which differences in floristic composition can be connected to these regimes. Taking into account what is known about the ecology of plants of West African savannas, the assessment of the mutual information between the fire regimes and the presence of the species within the landscapes affected by given fire regimes will help to specify both the accuracy of the MODIS data and the impact of fire regimes on phytodiversity.

\section{Study area}

The zone studied extends from $11^{\circ}$ to $12^{\circ} 2^{\prime}$ latitude North in western Burkina Faso (in the provinces of Houet, Tuy, Balé, Mouhoun and Sanguié). The climatic and ecological conditions range from South sudanian with 900 to $1100 \mathrm{~mm}$ annual rainfall and 5 to 6 dry months (with under $50 \mathrm{~mm}$ rainfall) to North sudanian with 800 to $900 \mathrm{~mm}$ annual rainfall and 6 to 7 dry months (about November and October to April) (Fontès \& Guinko 1995) (figure 1). 


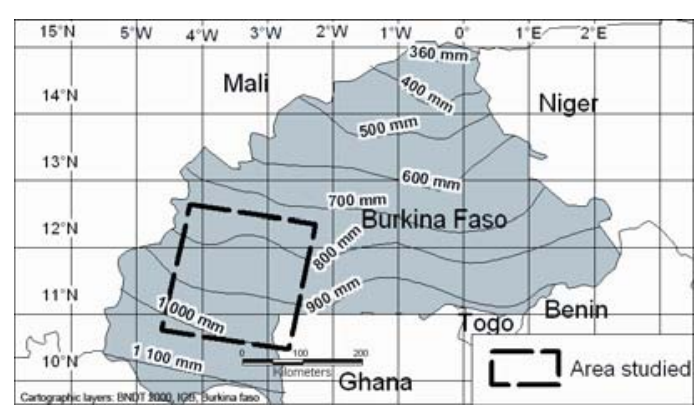

Figure 1 -Localisation of the area studied (Landsat ETM+ 196_052 scene)

The whole zone is part of the "cotton area”, with agriculture based mainly on sorghum, millet, groundnuts and some legumes; but the agricultural production in the South sudanian zone is more intensive and more varied, especially as a result of the cultivation of yams and of perennial crops (mangos, citrus fruits, cashew nuts, etc.). The region studied includes many protected areas that succeed one another along the Mouhoun river and a South-North climatic gradient from the "Mare aux Hippopotames” Biosphere Reserve to the Tiogo "Forêt Classée". Fire-prone savannas cover the whole zone, but due to increasing climatic dryness various floristic and physiognomic changes are observed: patch forests or gallery forests become scarce northward, while deciduous trees become more abundant, e.g. the higher frequency of Acacia species (Wittig et al. 2004).

Strict laws provide for the regulation and management of fire in the rural areas and watchwords against the abusive cutting of wood, the divagation of animals and the bush fires were even given during the "three fights” period (1985) in Burkina Faso. In spite of that, fire indeed remains a fundamental characteristic of the savanna ecosystem in the West of Burkina Faso, as more generally in African savannas (Ampadu-Agyei 1998). More pragmatic legal approaches were subsequently adopted by distinguishing management and customary ritual fires from bush fires (Government of Burkina Faso 1998, Grégoire et al. 2003, Laris \& Wardell 2006). Nowadays bush fires, defined as uncontrolled, are prohibited; the other types are tolerated, but in a precise framework. The management fires must be under the control of their perpetrators; , they are typically clearing fires and "early" fires lit in order to settle or clean cultivation fields. They also include technical management fires such as for the maintenance of pastoral areas and for the conservation of protected areas (national parks, game reserve, state forests). Ritual fires, which may be lit in different places as part of customary ceremonies, must be supervised both by the State and the traditional authorities and, most of all, controlled. This new realistic legislation is more consistent with everyday practices in most countries in West Africa, since rural populations use fires as a working tool for agricultural purposes, for pasture management and for hunting (Bruzon 1994). In addition, 
ritual fire is a still deeply rooted practice, as shown by Dugast (2006, 2008) who put in light the social and symbolic character of the yearly ritual burning of holy sites among Bwaba (Burkina Faso) and Bassar (Togo) societies.

\section{Materials and methods}

\section{Acquisition and calculation of MODIS data}

We used the $1 \mathrm{~km}$ resolution 8- day summaries of the MODIS active fire data (MOD14A2 and MYD14A2). Products were downloaded thanks to the NASA Land Processes Distributed Active Archive Center (LP-DAAC) anonymous FTP server (tp://e4ftl01u.ecs.nasa.gov/ ). The period studied goes from 2000.03.05 to 2008.06.30 and the zone studied was extracted from the tile h17v07.

We also downloaded the Monthly Tiled 500 m Burned Area Product (MCD45A1) from the ftp server ftp://ba1.geog.umd.edu/ . Data acquired (the last on 2008.06.27) goes from 2000.09 to 2008.04, but 2004.09 to 2004.12 were missing.

Thanks to the MODIS Reprojection Tool (MRT v4.0), the MODIS "hdf" files were transformed into a GEOTIFF format to be worked with the MAPINFO software.

For MOD14 and MYD14, we considered pixel class higher than or equal to 7 as fire pixel. For MCD45A1 data, we considered pixel with a value of approximately Julian day of burning as burnt and all others as not burnt.

We compiled data according to four periods during the dry season: very early (Julian days (JD) 249-304), early (JD 305-365), late (JD 001-064) and very late fires (JD 065-151).

These limits are generally accepted for the area studied (Bationo et al. 2001 a et b, Laris, 2005, Ouédraogo \& Delvingt 2007), they take into account the shortening of the dry season from the South to the North of the area (Nielsen \& Rasmussen 1997, 2001) and are in accordance with the climatic seasonality and the phenological rhythms of the vegetation (Fournier 1991, 1994, Devineau 1997, 1999). In addition we compiled data on an annual basis.

We calculated 1) fire density as the number of pixels that got fire within given areas (the entire zone studied, specific areas such as protected areas, and the various land-cover and landform units) and 2) fire frequency as the return interval of fire (i.e. the number of years a pixel got fire relatively to the number of observed years). The fire return frequency per year was calculated considering together active fire and burnt area data. 


\section{Establishing relationships between surface variables and MODIS data}

Crossing MODIS fire data with land cover units previously established from ETM+ satellite data

The zone studied is exactly delimited by the 196-052 ETM + satellite scene of which three images on June 3, 2001, June 22, 2002 and December 28, 2001 were previously analysed. This former study defined eleven land-cover units according to vegetation cover and soils, both assessed by way of ETM+ remote sensing satellite data (Devineau et al. 2008). The land cover characteristics of each MODIS fire pixel can therefore be assessed as the proportion of ETM pixels (28,5 meters) classified in the eleven land cover units. The relationships between occurrences and frequencies of fire and land cover units can then be summarised in term of contingency tables (i. e. frequencies of ETM land cover classes belonging to MODIS fire classes) whose statistical significance can be evaluated by $\mathrm{Chi}^{2}$ tests and then factorized by correspondence analyses.

\section{Linking MODIS fire data to terrain surveys}

Terrain data are 635 vegetation relevés of a georeferenced database established for the area (Vidal et al 2006) and 50 supplementary observations ascertaining pre- and post-fire conditions in September and December 2008 for some precise MODIS fire classes. The vegetation relevés were founded on the classic phyto-sociological method of the homogeneous area. The sample-plot size (generally $40 * 40 \mathrm{~m}$ plots) was in practice a compromise that guaranteed a valid representation of the woody species diversity and made it possible to ensure the physiognomic homogeneity of the stand with regards to the physiognomy of the woody species community and dominant herbaceous species (Devineau 2005). The vegetation plots were investigated in every vegetation type along tracks distributed in the whole of the area studied, inside and outside protected areas. Each plot was geo-referenced and could be associated with a MODIS fire class and with an ETM+ landcover class as well. Because of the small size of the ETM pixel, the correspondence of the latter with terrain observations was always carefully verified.

The Mutual Information (MI) (Godron 1968, Daget \& Godron 1982, Steuer et al. 2002) and also a $\mathrm{Chi}^{2}$ test were calculated between species frequencies (considering presence data) and MODIS fire classes with the ADE4 software (Thioulouse et al. 1997). As MI and Chi² don't give fully corresponding results as to the significance of co-occurence, we considered that a link between a species and a fire regime could be established only when the MI of the species 
was equal at least to the lowest MI value corresponding with a significant $\mathrm{Chi}^{2}$ test (0.05). As both tests strongly differ in their discriminating efficiency they appear to be complementary. As a normalized value, the $\mathrm{Chi}^{2}$ is not reliable for low-frequency species, while the MI measures the connection between two variables whatever the number of individuals of the population, but doing so, the assessment may be biased towards rare species.

In order to know something of the opinion of villagers about fire change, questions were asked of 15 persons (croppers and herders) in ten localities between Bondoukuy and Dédougou (80 km apart) in September 2008. This informal enquiry aimed only at giving some clues for interpreting remote-sensing data.

\section{Results}

\section{Correspondence of fire regimes assessed by MODIS data with land-cover units}

\section{Differences between active fires and burned areas data}

The ability of active-fire-data and of burnt-area-data to account for areas affected by fire is somewhat different. During the whole period of observation, $42 \%$ of the area were indeed detected by both MODIS products as having been affected by fire and $26 \%$ as not having been burnt; but $24 \%$ of the areas affected by fire were detected only by active-fire-data and $8 \%$ only by burnt-area-data. These differences can however be related to land cover characteristics. The crossing between ETM land cover units and MODIS either burnt or active-fire-data shows that both are dependent (Chi ${ }^{2}$ test was significantly different from random distribution beyond the $99.9 \%$ level; this is also the case for all the following relationships among land cover, fire frequencies and seasonality and that will not be repeated). Unburnt areas correspond to the agricultural domain (fields, fallows of slopes and bottom-slopes) and to bare soils, in contrast active fire and burnt areas were detected together mainly on bushy savannas on gravelly soils and hardpan (figure 2). Areas only detected as burnt were mainly tree or open savannas, particularly on upperslopes that usually have a continuous herbaceous stratum but a low phytomass. Areas only detected as active fire places were mainly savanna woodlands of wet places, usually with high herbaceous phytomass, but typically fragmented. 


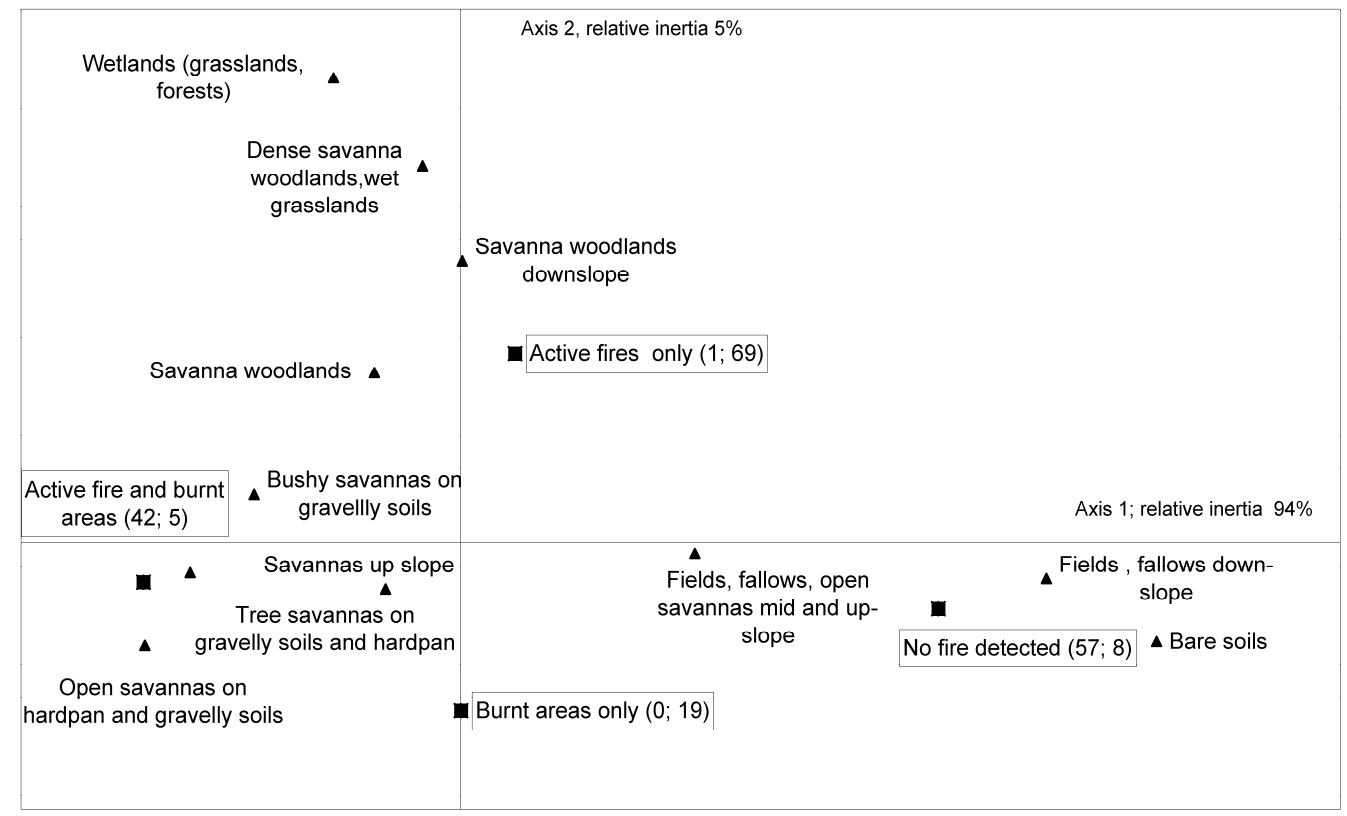

Figure 2 - Correspondence analysis between land cover units and type of fire detection: active fire or burnt areas (Western Burkina Faso). (Between brackets: absolute contribution of fire type to respectively the first and second axis)

Additional field observations confirmed these results. Areas where active fires were detected were characterised by high herbaceous biomasses and areas where active fire and burnt areas were jointly detected corresponded mainly with savannas on gravelly soils and hardpan complexes. Areas only detected as burnt areas had a rather continuous herbaceous stratum of lower biomasses. Areas where no fires were detected were mainly agricultural zones or village neighbourhoods characterised by very open treed savanna (parklands) or herbaceous fallows. Fires are however not always absent from such areas, where they can affect sparse patches of not very dense vegetation, but they are neither strong enough to be detected as active fire nor large enough to be detected as burnt areas. As an example, no fire was detected on a wide part of the South-West of the Sorobouly state forest, that corresponds to the illicit or tolerated establishment of fields; but between these fields, many small burnt areas were observed, which correspond to small places with a herbaceous cover of low biomass (e.g. patches of Loudetia togoensis, Elionurus elegans in scattered clumps and Michrocloa indica forming a low continuous cover) or to the burning of the leaf-litter of woody species under shrubby thickets. 


\section{Land cover and fire seasonality}

In order to study the variability of the seasonal density of fires according to landcover, we took into account the four seasonal periods (very early, early, late, and very late fires) and some of their combinations (these last ones taking into account the return of fire in several seasons on the same pixel). The great majority of the surface of the area studied was burnt between November and February, early fires (November-December) being obviously more dense and frequent (figure 3).

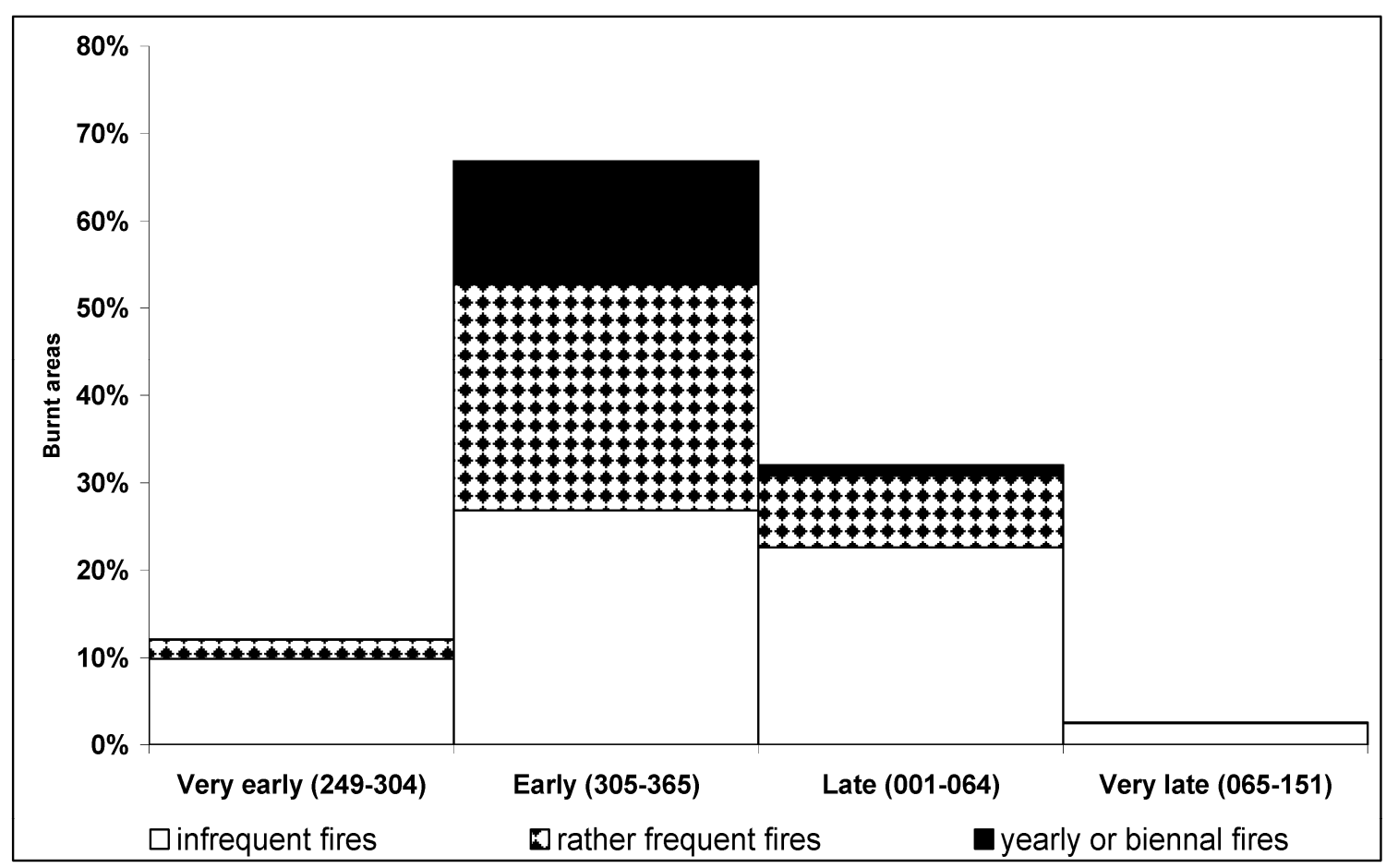

Figure 3 - Seasonal distribution of fires on the studied area in Western Burkina Faso (proportion of MODIS pixels that got fire during each season; data compiled from 2000 to 2008).

The seasonality of fires varied markedly however according to land cover. Agricultural zones on slopes and bare soils on bottom slopes appeared again as not burnt areas. Very early fires affected mainly open or herbaceous savannas on gravelly soils and hardpan. Seasonal fires return on the same pixels were observed mainly for tree and bushy savannas on complexes of gravelly soils and hardpan, whereas late and very late fires featured wet places (dense savannas and savanna woodlands on downslopes, wet grasslands etc.) and also some cultivated areas (e. g. fields and fallows on downslopes) as shown by the median position of the modalities "late" and "very late" relative to the positive part of axis 1 and to the negative part of axis 2 (figure 4). In addition fires occurred earlier in the drier parts of the area studied, 
in relation with the beginning of the dry season, but the pattern of fire seasonality according to land cover was nevertheless similar over the whole area.

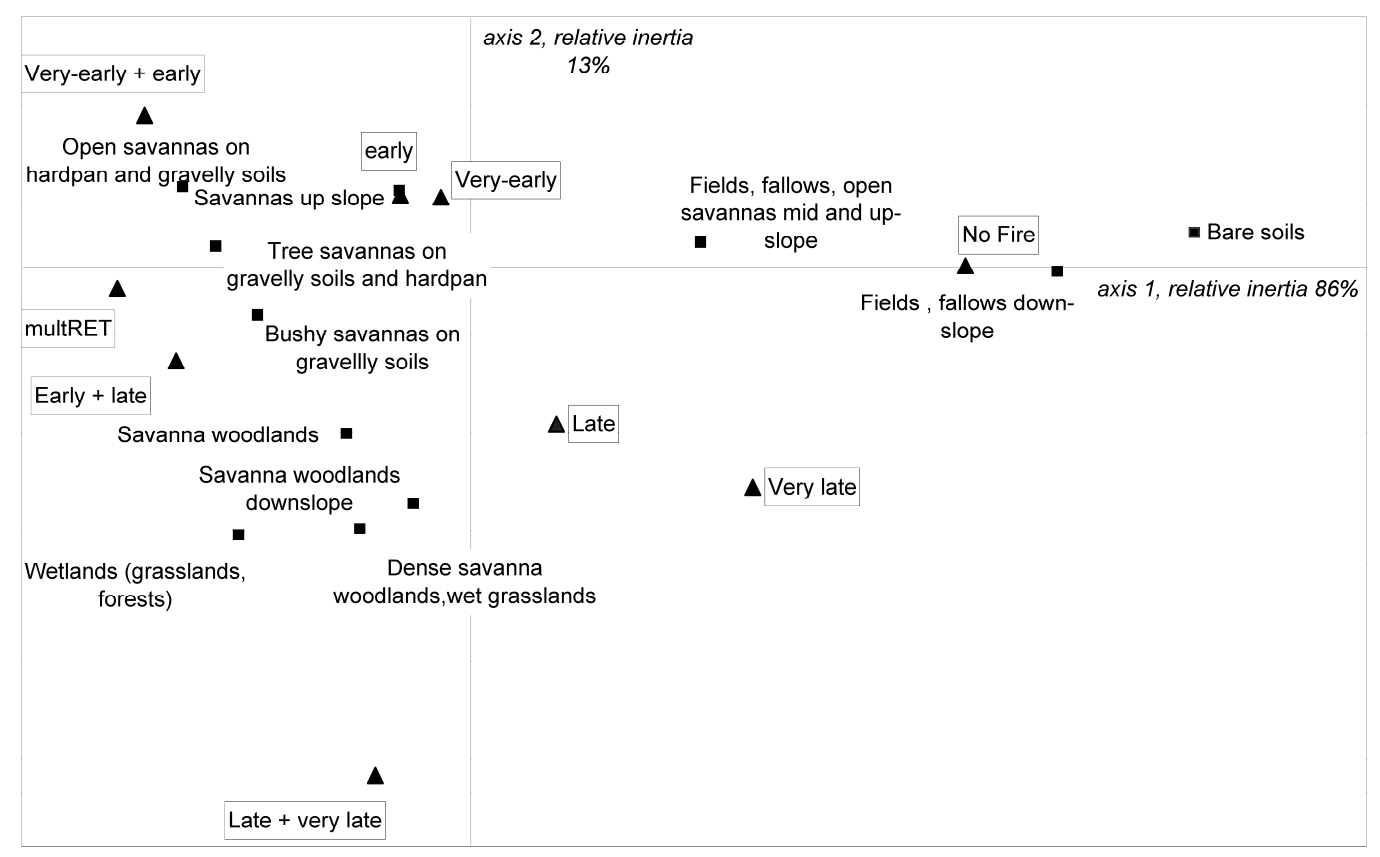

1 Figure 4 - Correspondence analysis between land cover units and seasonal occurrence of fires

(Western Burkina Faso)

\section{Variability of fire frequency according to land cover and land use}

The most frequent fires (yearly or biennal) were observed mainly on hardpan and gravelly soils. Fairly frequent fires were observed in all savanna formations, but fires were infrequent or missing on agricultural lands, in particular on lowlands, where cultivation is more intensive and fallows are sparser and shorter (figure 5). As a rule, yearly or biennial fires predominated in protected areas (table 1) but fires were however scarcer in those including wide areas poorly covered, in particular in the northern part of the zone studied (figure 6). 
Table 1 - Fire's regimes occurrence within and without protected areas (West Burkina Faso, area delimited by the 196-052 ETM + scene)

\begin{tabular}{|lcc|}
\hline & $\begin{array}{c}\text { inside } \\
\text { protected } \\
\text { areas }\end{array}$ & $\begin{array}{c}\text { outside } \\
\text { protected } \\
\text { areas }\end{array}$ \\
No Fire & $8.2 \%$ & $29.4 \%$ \\
Infrequent fires & $13.1 \%$ & $22.4 \%$ \\
Fairly frequent fires & $31.3 \%$ & $27.2 \%$ \\
Yearly or biennal fires & $47.4 \%$ & $21.0 \%$ \\
\hline
\end{tabular}

\begin{tabular}{|c|c|c|c|}
\hline & $\begin{array}{l}\text { Fields, fallows, open } \\
\text { savannas mid and up- } \\
\text { slope }\end{array}$ & \begin{tabular}{l|} 
axis 2; relative inertia $3 \%$ \\
\end{tabular} & $\begin{array}{l}\begin{array}{l}\text { Savanna woodlands } \\
\text { downslope } \\
\text { Dense savanna } \\
\text { woodlands,wet } \\
\text { grasslands }\end{array} \\
\text { - Savanna woodlands } \\
\text { Savannas up slope Bushy savannas on } \\
\text { gravellly soils }\end{array}$ \\
\hline $\begin{array}{l}\text { Fields, fallows down- } \\
\text { slope } \\
\text { - Bare soils }\end{array}$ & No fire & & $\begin{array}{l}\text { Tree savannas on } \\
\text { gravelly soils and hardpan } 1 \text {; relative inertia } 97 \% \\
\text { Open savannas on } \\
\text { Yearly or biennal fires }\end{array}$ \\
\hline
\end{tabular}

Figure 5 - Correspondence analysis between land cover units and fire frequencies (Western Burkina Faso 


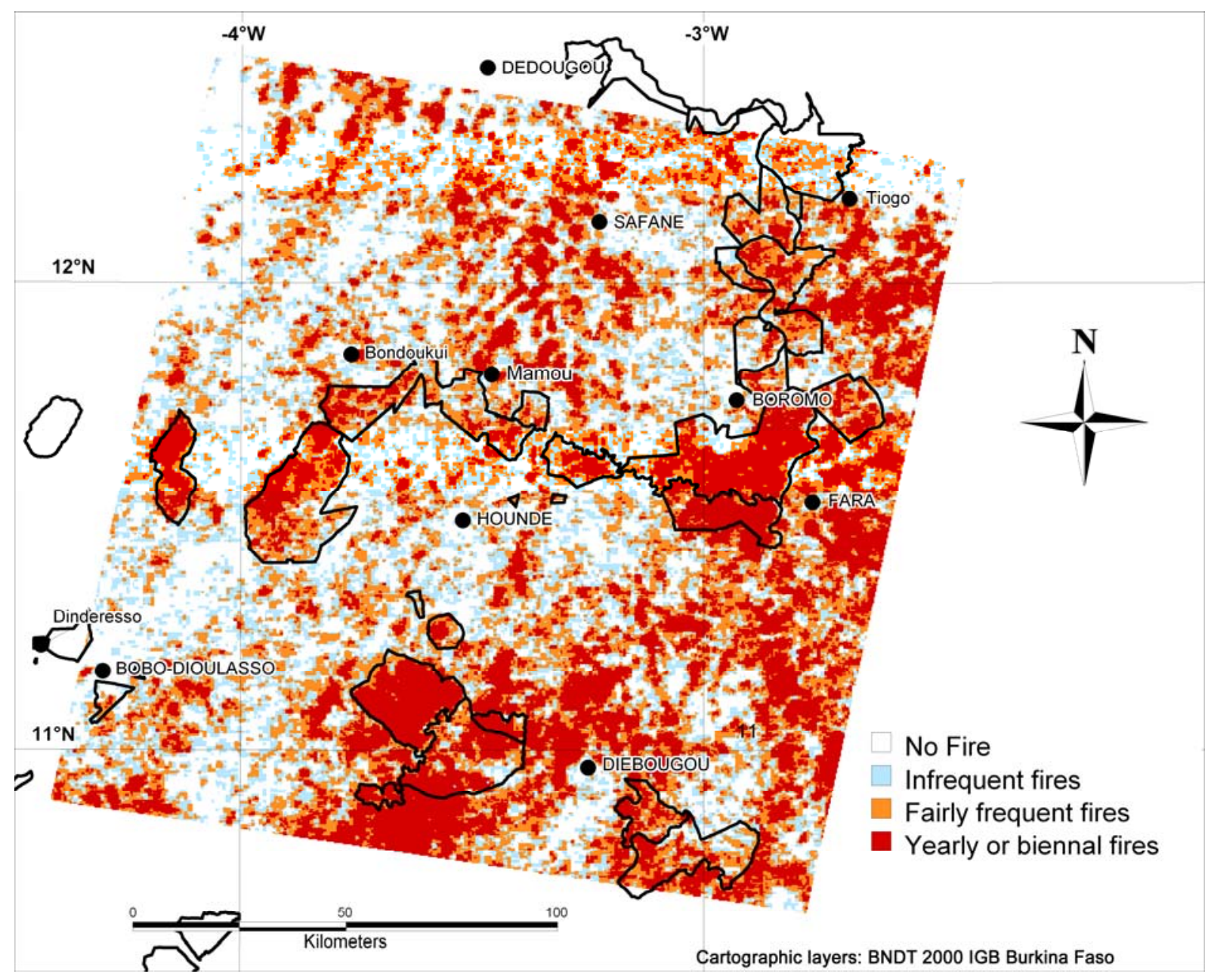

Figure 6 - Fire's frequency distribution in the area studied (protected areas are framed)

\section{Plant species distributions according to the fire regimes}

The assessment of mutual information showed up as statistically significant and ecologically meaningful links between the distribution of species and the fire regime units could be established by means of MODIS data. Fifty- one out of the 204 species studied were thus statistically significantly linked with fire units (see electronic supplementary data). The correspondence analysis of the frequency distribution profiles for these 51 species enables the characterisation of the species distributions according to fire regimes. It clearly appears that species distributions are organized according to two main groups, the first related to annual, biennal and fairly frequent fires, the second related with infrequent fires and the absence of detected fires (figure 7). With the exception of Vetiveria nigritana (a species of stream-sides and swampy areas), the second group consists of species with not very specific habitats or related mainly to open savannas and fallows in agricultural zones (table 2). 
Table 2. Species significantly linked with landscape fire's regimes in Western Burkina Faso (highest mutual information and H0 probability $<=0.05$ )

\begin{tabular}{|l|c|l|c|}
\hline Frequent, yearly, biennal fires & \multicolumn{2}{|l|}{ Infrequent fires or no fire } \\
\hline Woody & & Grasses and sedges & \\
\hline Afzelia africana & Afaf & Aristida sieberana & Arsi \\
\hline Bombax costatum & Boco & Bulbostylis abortiva & Buab \\
\hline Burkea africana & Buaf & Ctenium newtonii & Ctne \\
\hline Entada africana & Enaf & Cyperus rotundus & Cyro \\
\hline Prosopis africana & Praf & Cymbopogon schoenanthus & Cysc \\
\hline Pterocarpus erinaceus & Pter & Digitaria debilis & Dide \\
\hline Grasses & & Euclasta condylotricha & Euco \\
\hline Andropogon tectorum & Ante & Microchloa indica & Miin \\
\hline Diheteropogon hagerupii & Diha & Paspalum scrobiculatum & Pasc \\
\hline Hyparrhenia smithiana & Hysm & Vetiveria nigritana & Veni \\
\hline Loudetiopsis kerstingii & Loke & Forbs & \\
\hline Schizachyrium sanguineum & Scsa & Amorphophallus aphyllus & Amap \\
\hline Forbs & & Cochlospermum tinctorium & Coti \\
\hline Raphionacme daronii & Rada & Crotalaria retusa & Crre \\
\hline Sub-shrubs & & Curculigo pilosa & Cupi \\
\hline Cochlospermum planchoni & Copl & Evolvulus alsinoides & Eval \\
\hline Climbers & & Fadogia agrestis & Faag \\
\hline Asparagus africanus & Asaf & Gladiolus gregarius & Glgr \\
\hline Cissus populnea & Cipo & Indigofera stenophylla & Inst \\
\hline Baissea multiflora & Bamu & Lantana rhodesiensis & Larh \\
\hline Infrequent fires or no fire & & Pandiaka involucrata & Pain \\
\hline Woody & & Schwenckia americana & Scam \\
\hline Azadirachta indica & Spermacoce chaetocephala & Spch \\
\hline Diospyros mespiliformis & Spermacoce radiata & Spra \\
\hline Gardenia erubescens & Spermacoce stachydea & Spst \\
\hline Grewia barteri & Guse & Tephrosia pedicellata & Tepe \\
\hline Guiera senegalensis & Climbers & Cissus diffusiflora & Wain \\
\hline Ozoroa insignis & & Cissus lelyi \\
\hline Terminalia avicennioides & & Cile \\
\hline
\end{tabular}

The first group contains relatively more trees, perennial herbaceous species and endemic species (soudano-zambesian) than the second group where shrubs, herbaceous annuals, widespread species, weeds and potential invaders are more numerous (figure 8). 


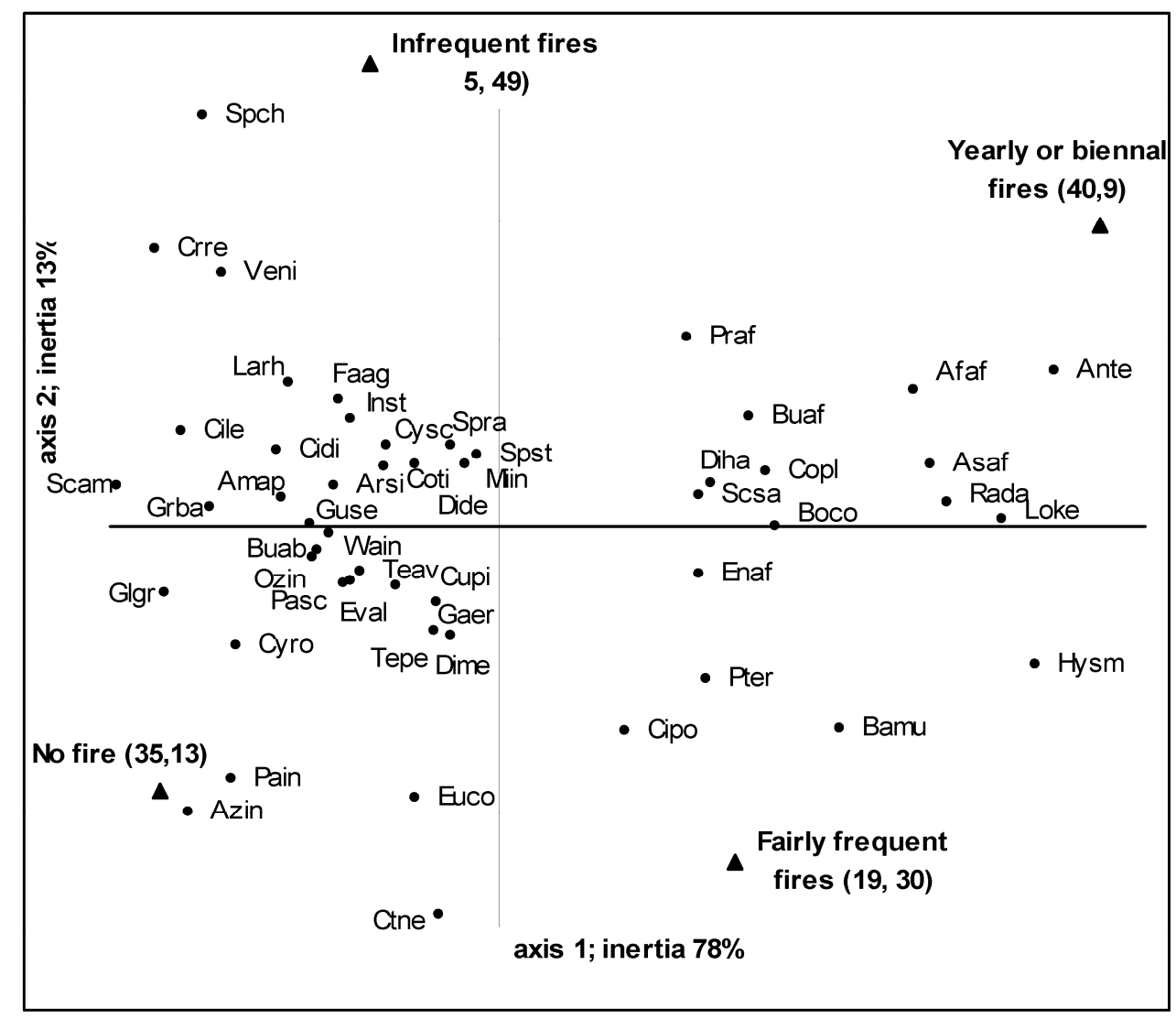

Figure 7 - Correspondence analysis between species and fire frequency (species significantly linked to fire's regime) (between brackets: absolute contribution of fire frequency regimes to respectively the first and second axis) 


\section{Life Forms}

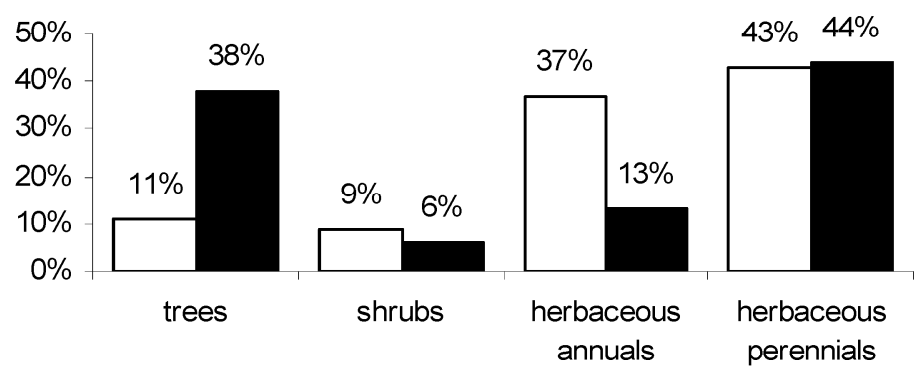

Geographical range

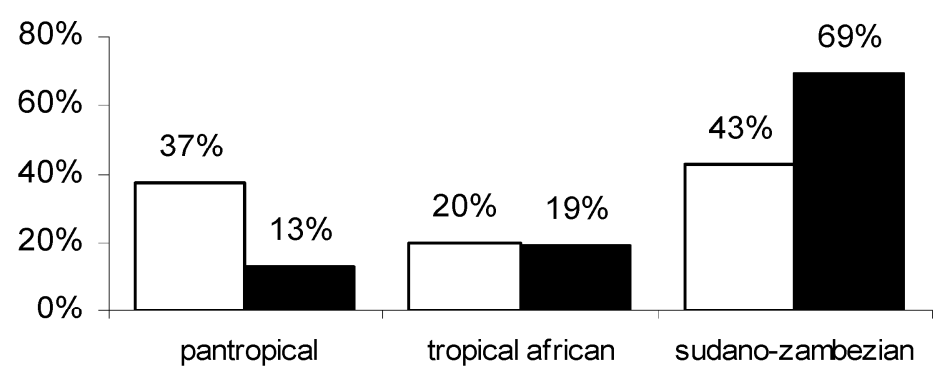

Potential threats

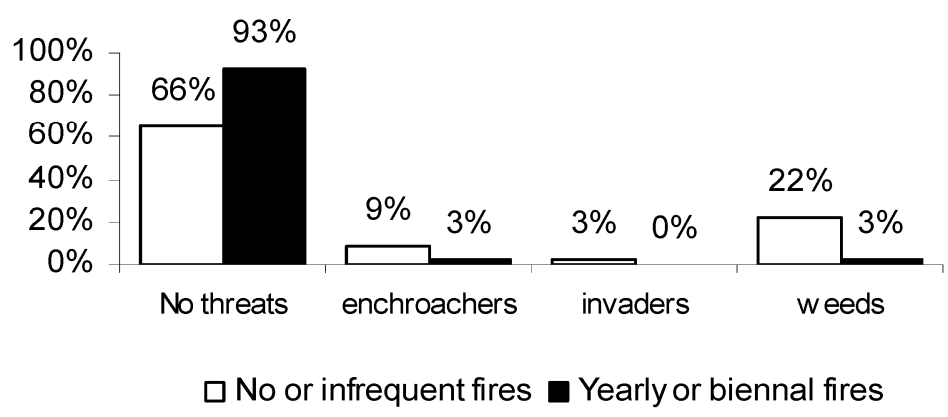

Figure 8 - Life traits of species significantly linked to fire’s regime units.

\section{Discussion and conclusion}

The current study shows how joining MODIS active fires and MODIS burnt areas data can be helpful to understanding the link between fire and landscape type in sudanian savannas. Active fire data successfully detects some sparsely patched flammable environments too small to be identified by burnt area data. On the other hand, burnt area data reveals not very productive environments, barely visible for the active fire sensors. Both types of data are thus needed as complementary tools to characterise the savanna fire regimes.

On the basis of fire seasonality and frequency, we established landscape fire units and assessed then their dependence on land cover and land use. As quoted by Nielsen \& Rasmussen (2001) the higher the land use intensity, the lower the fire frequency: indeed our 
results attest the high frequency of fire inside protected areas and on gravelly soils and hardpan complexes unsuitable for agriculture. They also confirm that the majority of fires take place in savanna-woodlands as shown by previous studies (Nielsen \& Rasmussen 2001, Clerici 2006, Grégoire \& Simonetti 2007). Overall, our results confirm that fire occurrence is influenced primarily by land use practice (Hudak et al. 2004). Conversely the decrease in the herbaceous standing crop, due to the shortening of the fallow period (Fournier 1991, Fournier 1994, Fournier \& Nignan 1997, Fournier et al. 2001), the extension of cultivated and cleared fields, and more generally the increment in landscape discontinuities limit the spread of fire and the size of burnt areas (Devineau 1986, Clerici 2006, Dolidon 2007). Because of the high impact of agriculture in the area studied (cotton zone) the area burnt annually is relatively limited outside protected areas (21\%) whereas $29 \%$ appeared as not burnt. Conversely $47 \%$ of the protected areas are burnt and only $8 \%$ unburnt. These values are similar to those of Menaut et al. (1991) who found that $25-50 \%$ of the sudanian savanna in West Africa was burnt annually or with those of Eva and Lambin (1998b) who found that $28 \%$ of the sudanian savanna of Central Africa had been affected by fires during a year.

The comparison of active fire and burnt area data indicates that fire frequency and intensity are thus related mainly to the herbaceous layer continuity and phytomass. Fire density peaks in November-December; however fire seasonality depends on vegetation hygrophily, very early fires mainly affect savannas on gravelly soils and hardpan whereas late and very late fires are observed in wetlands, but also on agricultural lands in accordance with previous observations by Bruzon (1990) or Nielsen \& Rasmussen (2001). Moreover fire begins all the more early as the climate is dry. Field enquiries revealed a tendency towards fires later and later in agricultural areas because of a growing difficulty in controlling people In such increasingly crowded landscapes; the need for limiting fires was also reported several times (mainly by herders). With physical and biological changes in environment, this feeling could explain the observed patterns of fire distribution. Fire rarefaction in degraded savanna could indeed be due to changes in land management, in particular for pastoral activities for which burning annual grasses is rather prejudicial, contrary to the burning of the perennial grasses of the former "true” savanna (Fournier 1996 and September 2008 enquiries).

Furthermore, species frequency relationships with landscape fire regimes were established. Due to the initial pixel size $\left(1 \mathrm{~km}^{2}\right)$ the fire's type units however relate to savanna landscape fragments that juxtapose various biotopes or plant species habitats. Although the probability of exposure to fire for a species can be assumed to be a function of the density and the intensity of fires in the landscape matrix, the difference in scales in our studies does not make 
possible a direct approach of the sensitivity of the species to fire. The surfaces used for the observation of presence of a species in a habitat, and those used to characterise the type of fire in the landscape matrix in which this habitat is included are too different. Moreover the reasons for the more frequent presence of species in landscape fire units are indeed varied; they may express fire-regime preferences, but also situations of refuge.

In the cotton zone of western Burkina Faso, the influence of fire on the environment is more marked within than without protected areas. These state forests, parks etc. are protective of the sudanian savannas biotopes and hence undergo frequent fires (generally annual) that are one of their distinctive features. As expected, plant species statistically linked with frequent fire landscape units are typical of sudanian savanna: many are endemic to the sudanian area, many are perennial grasses -the constituent life form of sudanian savannas (Fournier $1991 \mathrm{p}$. 11 et 248), some are woody species typical of sudanian woodlands e. g. Prosopis africana, Afzelia africana (Stark 1986, De Wolf 1998, Bationo et al. 2001, Onana \& Devineau 2002). However some species regarded as rather fire sensitive e.g. Anogeissus leiocarpus, Tamarindus indica do not appear to be linked to any fire landscape units, because they are frequently hosted in refuge habitats (thickets, groves, termite mounds etc.) in fire- prone landscapes (Traoré et al. 2008, Liberski et al. 2009), which counterbalances their presence in rarely burnt or not burnt areas. Furthermore the preference of A. leiocarpus for the best lands (chemically rich) (Aubréville 1950, Von Maydell 1983), would explain its rarefaction in certain strongly exploited agricultural lands : in such conditions it occupies mainly gravelly soils and hardpan complexes (Devineau 2001, Liberski-Bagnoud et al. 2009). A seeming lack of specialization of a species can thus result from its elimination from its preferential habitats by a harmful disturbance. Two grass species give another example of a certain discrepancy or lack of precision in the links detected between species requirements and fire landscape units. Andropogon chinensis and Schizachyrium sanguineum are two perennial grass species typical of fire-proclimax tree savanna. S. sanguineum appears significantly linked to frequently burnt landscape units (table 2) but not $A$. chinensis. Certain features of these polymorphic species which have a wide distribution in the tropics can explain this. In sudanian environments they usually grow together as dominant species on sandy or gravelly soil in uncultivated areas, but their maximum abundance is on slightly to rather gravelly soils on plateaus for $A$. chinensis and on sandy and plainly gravelly soils on midslopes of hills for S. sanguineum. Both can also be found on old (over 20 year-) fallow land, where S. sanguineum comes somewhat later than A. chinensis in the succession. All in all the ecological range of A. chinensis is a little wider than that of $S$. sanguineum and is linked to soils more suitable for agriculture (Ouédraogo, 
1993). A. chinensis is thus more likely to be found in landscape units including cultivated (and hence not burnt) lands, although its preference is clearly for savannas or very old fallow lands.

The flora of lands slightly or not affected by fires thus reflects the chiefly agricultural nature of these areas: wide- ranging species and weeds are the main constituents of their flora, whereas the fire-sensitive species of the "dry forest" -such as Diospyros mespiliformis -are currently poorly represented there. Previous work in the region studied indeed showed that agricultural intensification leads to the establishment of wide-ranging species, particularly weeds and that, in addition to the dominance of some shrubby species were noteworthy characteristics of such lands, where they often became encroaching plants (Devineau et al. 2009). The groups of species significantly related to fire regimes actually include many weeds and potentially invasive species linked to unburnt units, as was observed in some other semiarid ecosystems (Macdonald \& Frame 1988, Puyravaud et al. 1995). Moreover some exotic species such as Azadirachta indica -the Neem tree, a native from tropical South East Asia typically linked to highly anthropized and fire-released lands can be locally naturalised or invasive. Similar observations were made in Guinean and Soudano-Guinean savannas where suppression or alleviation of fire favours exotic or invasive species such as the invasion of a fire protected savanana by Chromolaena odorata (Gautier 1996) or the establishment of Gmelina arborea and Tectona grandis on plots totally protected or managed with early fires (Louppe et al. 1995a \& b). It thus appears that unburnt landscape units are currently more sensitive and vulnerable to some biological threats than the burnt savannas. Although disturbances are often thought to favour invaders, in the present case it is the suppression of the disturbance which seems to support threatening processes (Buckley et al. 2007). As quoted by Wright (1974), fire may indeed provide the long-term stability needed to preserve the ecosystem; it can be seen as an incorporated disturbance that enables the savanna resilience and pseudo-stability, but whose disappearance is destabilizing (Holling 1973, Allen \& Starr, 1982, Bergkamp 1995, Ingegnoli \& Pignatti 2007). Therefore the absence or the rarefaction of fires indicates land use intensification, but also ecosystems whose dynamics deviate from those of sudanian savannas.

\section{References}

Allen, T.E.H \& Starr. T.B. 1982. Hierarchy perspectives for ecological complexity. University of Chicago Press, Chicago. 
Ampadu-Agyei, O. 1998 Bushfires and management policies in Ghana. The Environmentalist 8(9): 221-228

Aubréville A. 1950. Flore forestière soudano-guinéenne. Société d'éditions géographiques. Société d'éditions géographiques, maritimes et coloniales. Paris.

Aubréville A., 1949 -Climat, forêt et désertification de l’Afrique tropicale, , Société d’édition de géographie maritime et coloniale, Paris.

Aubréville A.1953 Les expériences de reconstitution de la savane boisée en Côte d'Ivoire. Bois et Forêts des Tropiques 32: 4-10.

Aubréville A.M.A 1947 The Disappearance of the Tropical Forests of Africa (La mort des forêts de l'Afrique tropicale) Unasylva 1(1) ([reproduced in Unasylva 1985, 37, 1827).http://www.fao.org/docrep/x5339e/x5339e04.htm\#the\%20disappearance\%20of\%2 0the\%20tropical\%20forests\%20of\%20africa

Backer, D.M., Jensen, S.E. \& McPherson G.R. 2004 Impacts of Fire-Suppression Activities on Natural Communities Conservation Biology 18(4):937-946.

Bationo, B.A., Ouedraogo, S.J. \& Guinko S. 2001a Longévité des graines et contraintes à la survie des plantules d’Afzelia africana Sm. dans une savane boisée du Burkina Faso Ann. For. Sci. 58 69-75

Bationo, B.A., Ouedraogo, S. J. \& Guinko, S. 2001b Stratégies de régénération naturelle de Detarium microcarpum dans la forêt classée de Nazinon (Burkina Faso). Fruits, 56 : 271-285

Beerling, D.J. \& Osborne, C.P. 2006 The origin of the savanna biome. Global Change Biology 12(11): 2023-2031

Bergkamp G. 1995 A hierarchical approach for desertification assessment Environmental Monitoring and Assessment 37(1): 59-78.

Bond, W. J. Woodward, F. I.. Midgley G. F. 2005 The global distribution of ecosystems in a world without fire. New Phytologist 165(2): 525-538

Bruzon V., 1990, « Les savanes du Nord de la Côte d’Ivoire. Mésologie et dynamique : l'herbe, le feu et le pâturage », Thèse de doctorat, Université de Paris, 301 p.

Bruzon V., 1994, « Les pratiques du feu en Afrique subhumide, exemple des milieux savanicoles de la Centrafrique et de la Côte d'Ivoire », in Blanc Pamard Ch., Boutrais J., À la croisée des chemins, Paris, Orstom, 147-163.

Buckley Y.M, Bolker B.M., Rees M. 2007 Disturbance, invasion and re-invasion: managing the weed-shaped hole in disturbed ecosystems Ecology Letters 10(9): 809-817 
Chuvieco, E., Giglio, L. \& Justice, C. 2008 Global characterization of fire activity: toward defining fire regimes from Earth observation data Global Change Biology 14 (7), 1488-1502 Climatic and Biospheric Implications, MIT Press, Cambridge, MA.: 133143

Clerici N 2006 Monitoring and assessing fire impacts and land-cover change in tropical and subtropical ecosystems using satellite remote sensing and GIS techniques. Phd thesis $86 \mathrm{p}$.

Daget, P. \& Godron, M. 1982 Analyse fréquentielle de l'écologie des espèces dans les communautés. Masson, Paris. 1-163.

D'Antonio C M \& Vitousek P M ; 1992 Biological Invasions by Exotic Grasses, the Grass/Fire Cycle, and Global Change. Annual Review of Ecology and Systematics. 23: 63-87(doi: 10.1146/annurev.es.23.110192.000431)

de Klerk H 2008 A pragmatic assessment of the usefulness of the MODIS (Terra and Aqua) 1-km active fire (MOD14A2 and MYD14A2) products for mapping fires in the fynbos biome. International Journal of Wildland Fire 17, 166-178.

Dellasala D.A., William, J.E., William C.D. \& Franklin J.F. 2004 Beyond Smoke and Mirrors: a Synthesis of Fire Policy and Science; Conservation Biology 18(4): 976-986

De Wolf, J. 1998 Species composition and structure of the woody vegetation of the Middle Casamance region (Senegal), Forest Ecology and Management, 111(2-3): 249-264

Devineau J.L. 1984 Structure et dynamique de quelques forêts tropophiles de l'Ouest africain. Travaux des chercheurs de Lamto $n^{\circ} 5$, Programme MAB savanes ISSN0294- 1422, ISBN 2- 7268- 0108- 8

Devineau J.L. 1986 Impact écologique de la recolonisation des zones libérées de l'Onchocercose dans les vallées Burkinabé (Nazinon, Nakambé, Mouhoun, Bougouriba). Rapport final OMS- Orstom, vol. I, 109 p.

Devineau J.L. 1997 Évolution saisonnière et taux d'accroissement des surfaces terrières des ligneux dans quelques peuplements savanicoles soudaniens de l’0uest burkinabé. Écologie 28(3): 217- 232.

Devineau J.L. 1999. Seasonal rhythms and phenological plasticity of savanna woody species in a fallow-farming system (South West Burkina Faso). Journal of Tropical Ecology, 15: 497-513 (doi:10.1017/S0266467499000978)

Devineau, J.L., 2001. Les espèces ligneuses indicatrices des sols dans des savanes et jachères de l’Ouest du Burkina Faso. Phytocoenologia. 31(3): 325-351. 
Devineau, J.L. 2005. Generalist versus specialist: a contrasted sociology of woody and herbaceous species in a fallow-land rotation system in the West African savanna (Bondoukuy, Western Burkina Faso), Phytocoenologia 35(1) 53-78 DOI:10.1127/0340-269X/2005/0035-0053

Devineau J.L., Aurouet, A., Douanio M. \& Hladik A. 2008 Changes in the availability and uses of wild yams according to climatic dryness and land-cover in Western Burkina Faso (West Africa): a joint ecological and ethno-botanical approach using GIS and remote sensing. Biodiversity \& Conservation 17(8): 1937-1963

Devineau, J.L., Fournier A. \& Nignan, S. 2009. "Ordinary biodiversity" in western Burkina Faso (West Africa): what vegetation do the state forests conserve? Biodiversity \& Conservation DOI 10.1007/s10531-008-9574-2

Doe, 2008 Fire management policy and environmental NGO movement: critical contemporary perspectives, indicators and prospects in savannas, Ghana. GeoJournal. 71( 2-3 ): 159-170.

Dolidon, H. 2005. L'espace des feux en Afrique de l'ouest. L'analyse spatio-temporelle d'un phénomène d'interface nature/société. Thesis. Caen University : 414 p.

Dolidon, H. 2007 The multiplicity of scales in the analysis of a phenomenon at the nature/society interface. The example of bushfires in West Africa. Cybergeo: 363 : 20p. http://www.cybergeo.presse.fr

Dugast St. 2006 Des sites sacrés à incendier. Feux rituels et bosquets sacrés chez les Bwaba du Burkina Faso et les Bassar du Togo », Anthropos, 101(2): 413- 427.

Dugast St. 2008. Incendies rituels et bois sacrés en Afrique de l’Ouest : une complémentarité méconnue, Bois et Forêts des Tropiques, 296 (2) : 17-26

Fontès J, Guinko S (1995) Carte de la végétation et de l’occupation du sol (Burkina Faso). Note explicative. Laboratoire d’Ecologie Terrestre, Institut de la Carte Internationale de la Végétation. CNRS, Université de Toulouse III (France) / Institut du Développement Rural, Faculté des Sciences et Techniques, Université de Ouagadougou (Burkina Faso)

Fournier, A., 1991. Phénologie, croissance et production végétales dans quelques savanes d’Afrique de l’Ouest. Variations selon un gradient climatique. Orstom éditeur, Paris, Études et thèses, 312 p.

Fournier, A 1994. Cycle saisonnier et production nette de la matière végétale herbacée en savanes soudaniennes pâturées : les jachères de la région de Bondoukuy (Burkina Faso) Ecologie, t. 25 (3) 1994: 173-188. 
Fournier, A, 1996 Dans quelle mesure la production nette de matière végétale herbacée dans les jachères en savane soudanienne est-elle utilisable pour le pâturage? Actes atelier : « La jachère, lieu de production », Bobo-Dioulasso, 2-4 octobre 1996. Recherche sur l'amélioration et la gestion de la jachère en Afrique de l'Ouest. Publication CORAF

Fournier A, Floret Ch, Gnahoua G M (2001) Végétation des jachères et succession postculturale en Afrique tropicale In: Floret Ch, Pontanier R (Eds ): La jachère en Afrique tropicale. De la jachère naturelle à la jachère améliorée. Le point des connaissances, vol. 2 John Libey Eurotext, Paris, pp 123-168

Fournier, A, Nignan, S., 1997. Quand les annuelles bloquent la succession post culturale. Expérimentation sur Andropogon gayanus en savane soudanienne (Bondoukuy, Burkina Faso). Écologie 28 (1), 13-21.

Frost PGH, Robertson F. 1987. The ecological effects of fire in savannas. In: Walker BH Determinants of Tropical Savannas. Miami, FL, USA: ICSU Press, 93-140.

Gauthier L, 1996. Establishment of Chromolaena odorata in a savanna protected from fire: an example from Lamto, central Côte d'Ivoire. In: U.K. Prasad, R. Muniappan, P. Ferrar, J.P. Aeschlimann and H. de Foresta, Editors, Distribution, Ecology and Management of Chromolaena odorata, Proc. 3rd Int. Chromolaena Workshop Abidjan, Côte d'Ivoire, November 1993, Agric. Exp. Station, University of Guam, Mangilao, Guam, USA Publication no. 202 (1996), pp. 54-67. visited on line 2009-01-21 http://www.ehs.cdu.edu.au/chromolaena/proceedings/third/3gaut.html

Getzin, M. 2002 Formation and Consequences of Fire-Induced Structures in Tropical and Sub-Tropical Savannas Thesis, Institut for Biochemistry and Biology University of Postdam: 96 p.

Giglio L, Loboda T., Roy D. P, Quayle B., Justice C. O., 2009 An active-fire based burned area mapping algorithm for the MODIS sensor, Remote Sensing of Environment, 113 (2): 408-420

Giglio, L., van der Werf, G. R., Randerson, J. T., Collatz G. J., \& Kasibhatla, P. Global estimation of burned area using MODIS active fire observations Atmos. Chem. Phys. Discuss., 5, 11091-11141, 2005 www.atmos-chem-phys.org/acpd/5/11091/

Giglio,L. 2005 MODIS Collection 4 Active Fire Product User's Guide on line visited 07/10/08 http://modis-fire.umd.edu/documents/MODIS_Fire_Users_Guide_2.2.pdf Gillon, D. (1983). The fire problem in tropical savannas. In: Tropical Savannas (ed. Bouliére, F.). Elsevier, Amsterdam, pp. 617-641. 
Glover P. E. 1968 The role of fire and other influences on the savannah habitat, with suggestions for further research African Journal of Ecology. 6 1): 131-137

Godron M., 1968 Quelques applications de la notion de fréquence en écologie végétale (recouvrement, information mutuelle entre espèces et facteurs écologiques, échantillonnage), Ecologia Plantarum III: 185-212

Goldammer, J.G. \& Price, C. 1998 Potential Impacts of Climate Change on Fire. Climatic Change 39(2): 273-296.

Govender, N., Trollope, W.S. W. \& Van Wilgen, B.W. 2006 -The effect of fire season, fire frequency, rainfall and management on fire intensity in savanna vegetation in South Africa. Journal of Applied Ecology 43 (4), 748-758.

Government of Burkina Faso 1998 Decrét no. 98-310/PRES/PM/MEE/ MATS portant utilisation des feux en milieu rural au Burkina Faso

Grégoire J-M. \& Simonetti D. 2007 Dynamique des brûlis dans le Parc Régional du W,le Parc National de La Boucle de la Pendjari et la Réserve d’Arly Implications pour la gestion de ces aires protégées European Commission Joint Research Centre Institute for Environment and Sustainability $49 \mathrm{p}$.

Grégoire, J.M., Fournier, A., Eva, H. Sawadogo, L., 2003 Caractérisation de la dynamique des feux et de l'évolution du couvert végétal dans le Parc du W : Burkina Faso, Niger et Bénin.. Mission d'expertise pour l'étude des feux de brousse et leur utilisation dans le cadre d'une gestion raisonnée des aires protégées du complexe WAP. 64 p

Hennenberg, K.J., Fischer, F., Kouadio, K., Goetze, D., Orthmann, B., Linsenmair, K.E., Jeltsch, F. \& Porembski, S. (2006). Phytomass and fire occurrence along forestsavanna transects in the Comoé National Park, Ivory Coast

Hoffmann, W. A.; 1999 - Fire and Population Dynamics of Woody Plants in a Neotropical Savanna: Matrix Model Projections. Ecology 80(4): 1354-1369.

Hoffmann, W.A., Schroeder, W. \& Jackson, R.B.; 2002 Positive feedbacks of fire, climate, and vegetation and the conversion of tropical savanna. Geophysical Research Letters, 29 (22): 2052-2055 , doi:10.1029/2002GL015424, 2002

Holling, C.S. 1973. Resilience and stability of ecological systems. Annual Review of Ecology and Systematics 4: 1-24.

Hudak A. T, Fairbanks D.H.K. \& Brocket, B. H. 2004 Trends in fire patterns in a southern African savanna under alternative land use practices Agriculture, Ecosystems \& Environment 101(2-3): 307-325 
Ingegnoli V. \& Pignatti S. 2007 The impact of the widened landscape ecology on vegetation science: towards the new paradigm Rendiconti Lincei 18(2): 89-122.

IWMI (2006) Climate and water atlas [online] http://dw.iwmi.org/dataplatform/ visited 13/09/2006

Justice C, Giglio L Boschetti L., Roy D; Csiszar, I., Morisette J. \& Kaufman Y. 2006 Modis Fire Products (Version 2.3, 1 October 2006) on line visited 06/10/08 http://modis.gsfc.nasa.gov/data/atbd/atbd_mod14.pdf

Justice, C. O., Giglio, L., Korontzi, S., Owens, J., Morisette, J., Roy, D., Descloitres, J., Alleaume, S., Petitcolin, F. \& Kaufman, Y., 2002, The MODIS fire products. Remote Sensing of Environment, 83:244-262.

Kasischke, E. S., and M. R. Turetsky 2006, Recent changes in the fire regime across the North American boreal region-Spatial and temporal patterns of burning across Canada and Alaska, Geophys. Res. Lett., 33, L09703, doi:10.1029/ 2006GL025677.

Keeley J. E \& Bond W. J 2001 On Incorporating Fire into Our Thinking about Natural Ecosystems: A Response to Saha and Howe The American Naturalist 158( 6): 664670.

Kerr J.T. and Ostrovsky M. 2003, From space to species: ecological applications for remote sensing, Trends in Ecology and Evolution 18(.6 ): 299-305.

Laris, P.S. 2005 - Spatiotemporal problems with detecting and mapping mosaic fire regimes with coarse-resolution satellite data in savanna environments Remote Sensing of Environment. 99(4): 412-42

Laris P., 2002 Burning the Seasonal Mosaic: Preventative Burning Strategies in the Wooded Savanna of Southern Mali Human Ecology 30 (2): 155-186, June 2002

Laris, P. \& Wardell, D.A. 2006- Good, bad or 'necessary evil'? Reinterpreting the colonial burning experiments in the savanna landscapes of West Africa. Geographical Journal $172(4), 271-290$.

Larrue, S. 2002 « Le Parc National du Niokolo-Koba : un exemple de rupture entre le milieu et la société mandingue (Sénégal Oriental) », in Cahiers d'outre-mer, 218, La gestion forestière dans les régions intertropicales, [On line], 13 février 2008. URL: http://com.revues.org/document1076.html. visited 10 /10/ 2008

Lentile, L.B., Holden, Z. A, Smith, A.M.S., Falkowski, M.J., Hudak, A.T., Morgan, P., Lewis, S.A., Gessler, P. E. \& Benson, N.C. 2006 Remote sensing techniques to assess active fire characteristics and post-fire effects. International Journal of Wildland Fire, 2006, 15 : 319-345 
Liberski-Bagnoud, D., Fournier, A. \& Nignan, S. 2009 Les « bois sacrés », faits et illusions.

Les sanctuaires boisés chez les Kasena du Burkina Faso. .......

Louppe, D., Ouattara, N., Coulibaly, A. 1995a Effets des feux de brousse sur la végétation.

Résultats après 60 années d’expérimentation Bois et Forêts des Tropiques 245 : 59-69

Louppe D., Ouattara N., Coulibaly A. 1995b. The effects of bush fires on vegetation. The Aubréville fire plots after 60 years Commonwealth Forestry Review, 74 (4) : 288-292.

Macdonald I.A.W. \& Frame, G.W.. 1988. The invasion of introduced species into nature reserves in tropical savannas and dry woodlands. Biol. Conservation 44: 67-93.

Mayaux, P., Eva, H., Fournier, A., Sawadogo, L., Palumbo, I. et Grégoire, J-M., 2007 Apport des techniques spatiales pour la gestion des aires protégées en Afrique de l'Ouest, in FOURNIER A., Sinsin B. \& MENSAH G.A. (eds) 2007. «Quelles aires protégées pour l'Afrique de l'Ouest ? Conservation de la biodiversité et développement ». Éditions de l'IRD, 607 p.

Mayaux, Ph., Fournier A., Grégoire J.M. 2003. Introduction : apport des techniques satellitales pour la gestion des aires protégées en Afrique sub-saharienne, in EVA et al., 2003, 1-7.

Mbow C., Sambou B., Tidiane Ba A. \& Goudiaby A. 2003 Vegetation and fire readiness in main morphological units of Niokolo Koba National Park (Southeast Senegal) Danish Journal of Geography 103(1): 55-62, 2003

Mbow, C., Nielsen, T. T., \& Rasmussen, K. (2000). Savannah fires in east-central Senegal: distribution patterns, resource management and perceptions. Human Ecology, 28(4), 561-583.

Menaut JC \& César J 1982 The structure and dynamics of a West African savanna in Huntley B and Walker B eds Ecology of tropical savannas Springer, New York 80-100

McKenzie, D., Gedalof Z., Peterson, D.L. \& Mote, P. 2004. Climatic Change, Wildfire, and Conservation. Conservation Biology 18(4): 890-902

Menaut, J. C., Abbadie L., Lavenu F., Loudjani P., Podaire A. Biomass burning in west African savannas, in Global Biomass Burning: Atmospheric, Climatic and Biospheric Implications, edited by J. S. Levine, pp. 133-142, MIT Press, Cambridge, Mass., 1991. Moreira, A.G. 2000 Effects of fire protection on savanna structure in Central Brazil. Journal of Biogeography 27(4) : 1021-1029.

Moretti M., C. Staehli, F. Gillet; 2008. Determinants for the conservation of a vulnerable firedependent species at its marginal range Plant Ecology 199(1): 89-98 
Morgan P, Hardy CC, Swetnam TW, Rollins MG, Long DG 2001 Mapping fire regimes across time and space: understanding coarse and fine-scale fire patterns. International Journal of Wildland Fire, 10, 329-342.

Neumann K, Müller-Haude P 1999 Forêts sèches au sud-ouest du Burkina Faso: Végétationsols-action de l'homme. Phytocoenologia 29 (1): 53-85.

New M, Lister D, Hulme M, Makin I 2002 A high-resolution data set of surface climate over global land areas. Clim Res 21(1):1-25

Nielsen T.T., Rasmussen K, Mbow C. \& Touré A., 2003 The fire regime of Senegal and its determinants Danish Journal of Geography 103(1): 43-53, 2003

Nielsen, T.T., and Rasmussen, K. 1997. The distribution in time and space of savanna fires in Burkina Faso, as determined from NOAA-AVHRR data. Danish Journal of Geography 97: 86-98.

Nielsen_\&_Rasmussen_2001 Utilization of NOAA AVHRR for assessing the the determinants of savanna fire distribution in Burkina Faso International Journal of Wildland Fire 10(2) 129 - 135

Onana, J. \& Devineau, J.L.; 2002. Afzelia africana Smith ex Persoon dans le Nord-Cameroun. Etat actuel des peuplements et utilisation pastorale. Revue Élev. Méd. vét. Pays trop. 55(1): 39-45.

Ouédraogo Mamadou., 1993. écologie comparée de deux espèces de graminées pérennes : Andropogon ascinodis C.B. Cl. et Schizachyrium sanguneum (Retz) Alston dans la région de Bondoukuy. Engineer master thesis, Ouagadougou university, 84 p.

Ouédraogo Moumouni, Delvingt W. 2007 L’impact des feux sur les strates herbacée et ligneuse, in Delvingt, W. \&; Vermeulen, C. eds. Nazinga, Les Presses Agronomiques de Gembloux, 312 p. on online http://www.bib.fsagx.ac.be/pressesdoc/Nazinga/feux.pdf visited 16/10/2008

Pausas J.G., Llovet J., Rodrigo A., Vallejo R 2008 Are wildfires a disaster in the Mediterranean basin? A review. International Journal of Wildland Fires

Roitman I., Felfili, J. M. \& Rezende A. V. 2008 Tree dynamics of a fire-protected cerrado sensu stricto. Plant Ecology, 197(2): 255-267

Roy, D. \& Boschetti, L. 2008. MODIS Collection 5 Burned Area Product MCD45 User’s Guide- on line visited 07/10/08 ftp://ba1.geog.umd.edu/MODIS_Burned_Area_Users_Guide_1.1.pdf 
Roy, DP, Frost, PGH, Justice, CO et al 2005 Southern Africa Fire Network (SAFNet) regional burned-area product-validation protocol. International Journal of Remote Sensing. 26 (19), 10 October 2005, 4265-4292

Scholes, R. J \& Archer. S. R. 1997 Tree-Grass Interactions in Savannas, Annual Review of Ecology and Systematics, 28: 517-544 (doi: 10.1146/annurev.ecolsys.28.1.517)

Stark, M. A.; 1986. Relationship between fire and basal scarring on Afzelia africana in Benoue National Park, Cameroon African Journal of Ecology 24(4): 263-271.

Steuer, R. Kurths, J. Daub, C. O. Weise, J. Selbig, J 2002 The mutual information: Detecting and evaluating dependencies between variables Bioinformatics, 18 (1), October 2002: $: 231-240$

Swaine, M.D. 1992 Characteristics of dry forest in West Africa and the influence of fire Journal of Vegetation Science 3(3): 365-374

Thioulouse, J., Chessel, D., Dolédec, S. \& Olivier, J.M. 1997. ADE-4: a multivariate analysis and graphical display software. Stat. Comput. 7: 75-83.

Van Langevelde et al 2003 - Effects of fire and herbivory on the stability of savanna ecosystems. Ecology, 84(2): 337-350

Von Maydell, H.J., 1983. Arbres et arbustes du Sahel. GTZ, Eschborn, 531 p.

Wheaton, E. 2001 Changing Fire Risk in a Changing Climate: A Literature Review and Assessment SRC Publication no. 11341-2E01, 33p.

Whitlock, C., Shafer, S.L \& Marlon, J. 2003 The Role of Climate and Vegetation Change in Shaping Past and Future Fire Regimes in the Northwestern U.S. and the Implications for Ecosystem Management - Forest Ecology and Management, 178(1-2):5-21

Vidal, M., Aurouet, A., Bourdin, P., Devineau, J.L., Pierre, D. Thomas, L. et Thomas, X. 2006 Un exemple d'interaction entre le substratum géologique et les écosystèmes : la cartographie du risque de ravinement par l'exploitation de la base/SIG " ECOSAV " pour les aires protégées de l'Ouest du Burkina-Faso. 21ème Colloque de Géologie Africaine, Maputo, 03-05.07.2006

Wiegand, K. Saltz, D. \& Ward, D. 2006 A patch-dynamics approach to savanna dynamics and woody plant encroachment - Insights from an arid savanna, Perspectives in Plant Ecology, Evolution and Systematics 7( 4): 229-242.

Williams, R. J., Cook. G.D., Gill A.M; \& Moore P.H. R. 2002. Fire regime, fire intensity and tree survival in a tropical savanna in northern Australia. Australian Journal of Ecology 24( 1): 50-59 
Wittig, R. Devineau, J.L. Fournier, A. 2004. L’importance du genre Acacia L. (Mimosaceae) pour la végétation du secteur soudanien du Burkina Faso. Etudes flor vég Burkina Faso 8: 45-50

Wright, H.E. 1974. Landscape development, forest fires, and wilderness management. Science 186: 487-495. 


\section{APPENDIX}

\section{Mutual information between species and fire regimes}

Output of the EcoTools program from ADE4 (Thioulouse et al. 1997)

Col 2-5: number of relevés in each fire regime unit where the species is present,

Total : total number of presence for the species,

Freq.: species frequency,

Entropy: descriptor's entropy (Daget \& Godron, 1982 p. 54),

MI: Mutual information between species and the descriptor (Daget \& Godron, 1982. p.50),

Khi²: observed $\mathrm{Khi}^{2}$,

Proba:, probability of exceeding the actual $\mathrm{Khi}^{2}$ value under the null hypothesis.

Daget, P. \& Godron, M. 1982. Analyse fréquentielle de l'écologie des espèces dans les communautés. Masson, Paris. 1-163.

Thioulouse, J., Chessel, D., Dolédec, S. \& Olivier, J.M. 1997. ADE-4: a multivariate analysis and graphical display software. Stat. Comput. 7: 75-83.

\begin{tabular}{|c|c|c|c|c|c|c|c|c|c|c|}
\hline \multirow[t]{2}{*}{ Species name } & \multicolumn{4}{|c|}{ Fire regime } & \multirow{3}{*}{ Total } & \multirow{3}{*}{ Freq. } & \multirow{3}{*}{ Entropy } & \multirow{3}{*}{ MI } & \multirow{3}{*}{$\mathrm{Khi}^{2}$} & \multirow{3}{*}{ Proba } \\
\hline & $\begin{array}{l}\text { No } \\
\text { fire }\end{array}$ & $\begin{array}{l}\text { Infrequen } \\
\text { fires }\end{array}$ & $\begin{array}{l}\text { Fairly } \\
\text { frequent } \\
\text { fires }\end{array}$ & $\begin{array}{l}\text { Yearly or } \\
\text { biennal } \\
\text { fires }\end{array}$ & & & & & & \\
\hline $\begin{array}{c}\text { Species statistically significantly } \\
\text { linked with fire units }\end{array}$ & & & & & & & & & & \\
\hline Guiera senegalensis J.F Gmelin & 56 & 51 & 33 & 8 & 148 & 0.233 & 0.783 & 0.033 & 27.81 & 0.00 \\
\hline $\begin{array}{l}\text { Cochlospermum planchonii Hook. } \\
\text { f. }\end{array}$ & 22 & 51 & 70 & 32 & 175 & 0.276 & 0.849 & 0.031 & 26.07 & 0.00 \\
\hline $\begin{array}{l}\text { Andropogon tectorum Schumach. } \\
\text { \& Thonn. }\end{array}$ & 1 & 9 & 16 & 13 & 39 & 0.061 & 0.333 & 0.029 & 24.87 & 0.00 \\
\hline Waltheria indica L. & 54 & 53 & 38 & 7 & 152 & 0.239 & 0.794 & 0.029 & 23.72 & 0.00 \\
\hline Burkea africana Hook. F. & 12 & 41 & 49 & 20 & 122 & 0.192 & 0.706 & 0.026 & 19.45 & 0.00 \\
\hline Grewia barteri Burret & 26 & 24 & 12 & 1 & 63 & 0.099 & 0.466 & 0.026 & 19.47 & 0.00 \\
\hline $\begin{array}{l}\text { Hyparrhenia smithiana (Hook. F.) } \\
\text { Stapf }\end{array}$ & 3 & 4 & 18 & 10 & 35 & 0.055 & 0.308 & 0.023 & 20.06 & 0.00 \\
\hline $\begin{array}{l}\text { Amorphophallus aphyllus (Hook.) } \\
\text { Hutch. }\end{array}$ & 32 & 25 & 12 & 6 & 75 & 0.118 & 0.524 & 0.022 & 19.36 & 0.00 \\
\hline Terminalia avicennioides G. \& Perr. & 42 & 42 & 36 & 5 & 125 & 0.197 & 0.716 & 0.019 & 14.69 & 0.00 \\
\hline Pterocarpus erinaceus Poir. & 34 & 40 & 76 & 26 & 176 & 0.277 & 0.852 & 0.018 & 16.26 & 0.00 \\
\hline Entada africana Guill. \& Perr. & 25 & 42 & 66 & 21 & 154 & 0.243 & 0.799 & 0.015 & 13.27 & 0.00 \\
\hline Fadogia agrestis Schweinf ex Hiern & 26 & 33 & 17 & 5 & 81 & 0.128 & 0.551 & 0.015 & 12.48 & 0.01 \\
\hline $\begin{array}{l}\text { Pandiaka involucrata (Moq.) B.D. } \\
\text { Jacks. }\end{array}$ & 15 & 8 & 9 & 0 & 32 & 0.05 & 0.288 & 0.015 & 10.9 & 0.01 \\
\hline Afzelia africana Smith ex Pers. & 1 & 9 & 13 & 7 & 30 & 0.047 & 0.275 & 0.015 & 10.14 & 0.02 \\
\hline $\begin{array}{l}\text { Prosopis africana (Guill. \& Perr.) } \\
\text { Taub. }\end{array}$ & 19 & 27 & 21 & 21 & 88 & 0.139 & 0.581 & 0.014 & 14.26 & 0.00 \\
\hline Bombax costatum Pellegr. \& Vuillet & 10 & 22 & 35 & 14 & 81 & 0.128 & 0.551 & 0.014 & 11.15 & 0.01 \\
\hline Indigofera stenophylla Guill \& Perr & 19 & 29 & 18 & 2 & 68 & 0.107 & 0.491 & 0.014 & 10.97 & 0.01 \\
\hline $\begin{array}{l}\text { Gardenia erubescens Stapf \& } \\
\text { Hutch. }\end{array}$ & 46 & 49 & 53 & 8 & 156 & 0.246 & 0.804 & 0.014 & 10.43 & 0.02 \\
\hline $\begin{array}{l}\text { Gladiolus gregarius Welw. ex } \\
\text { Baker }\end{array}$ & 12 & 9 & 5 & 0 & 26 & 0.041 & 0.247 & 0.014 & 9.83 & 0.02 \\
\hline $\begin{array}{l}\text { Diospyros mespiliformis Hochst. ex } \\
\text { A. Rich. }\end{array}$ & 52 & 37 & 41 & 14 & 144 & 0.227 & 0.772 & 0.013 & 11.88 & 0.01 \\
\hline $\begin{array}{l}\text { Bulbostylis abortiva (Steud.) C.B. } \\
\text { Clarke }\end{array}$ & 27 & 23 & 16 & 4 & 70 & 0.11 & 0.501 & 0.013 & 11.05 & 0.01 \\
\hline Cymbopogon schoenanthus (L.) & 33 & 33 & 19 & 10 & 95 & 0.15 & 0.609 & 0.013 & 10.97 & 0.01 \\
\hline
\end{tabular}




\begin{tabular}{|c|c|c|c|c|c|c|c|c|c|c|}
\hline \multirow[t]{2}{*}{ Species name } & \multicolumn{4}{|c|}{ Fire regime } & \multirow[b]{2}{*}{ Total } & \multirow{3}{*}{ Freq. } & \multirow[b]{2}{*}{ Entropy } & \multirow{3}{*}{ MI } & \multirow[b]{2}{*}{$\mathrm{Khi}^{2}$} & \multirow[b]{2}{*}{ Proba } \\
\hline & $\begin{array}{l}\text { No } \\
\text { fire }\end{array}$ & $\begin{array}{l}\text { Infrequen } \\
\text { fires }\end{array}$ & $\begin{array}{l}\text { Fairly } \\
\text { frequent } \\
\text { fires }\end{array}$ & $\begin{array}{l}\text { Yearly or } \\
\text { biennal } \\
\text { fires }\end{array}$ & & & & & & \\
\hline \multicolumn{9}{|l|}{ Spreng. subsp. schoenanthus } & & \\
\hline Ctenium newtonii Hack & 15 & 7 & 18 & 1 & 41 & 0.065 & 0.345 & 0.013 & 9.65 & 0.02 \\
\hline Spermacoce chaetocephala DC. & 6 & 10 & 1 & 1 & 18 & 0.028 & 0.186 & 0.013 & 9.6 & 0.02 \\
\hline Vetiveria nigritana (Benth.) Stapf & 7 & 12 & 4 & 0 & 23 & 0.036 & 0.225 & 0.013 & 9.04 & 0.03 \\
\hline Cyperus rotundus L. & 13 & 10 & 8 & 0 & 31 & 0.049 & 0.281 & 0.013 & 8.2 & 0.04 \\
\hline $\begin{array}{l}\text { Loudetiopsis kerstingii (Pilger) } \\
\text { Conert }\end{array}$ & 2 & 4 & 10 & 7 & 23 & 0.036 & 0.225 & 0.012 & 10.99 & 0.01 \\
\hline Cochlospermum tinctorium A. Rich. & 29 & 38 & 27 & 5 & 99 & 0.156 & 0.624 & 0.012 & 9.96 & 0.02 \\
\hline Ozoroa insignis Del. & 24 & 21 & 15 & 3 & 63 & 0.099 & 0.466 & 0.012 & 9.93 & 0.02 \\
\hline Cissus diffusiflora (Baker) Planch. & 17 & 18 & 9 & 2 & 46 & 0.072 & 0.375 & 0.012 & 9.47 & 0.02 \\
\hline $\begin{array}{l}\text { Schizachyrium sanguineum (Retz) } \\
\text { Alston }\end{array}$ & 17 & 36 & 47 & 17 & 117 & 0.184 & 0.689 & 0.012 & 9.43 & 0.02 \\
\hline Aristida sieberana Trin. & 23 & 26 & 17 & 3 & 69 & 0.109 & 0.496 & 0.012 & 9.32 & 0.03 \\
\hline $\begin{array}{l}\text { Curculigo pilosa (Schum \& Thonn) } \\
\text { Engl }\end{array}$ & 31 & 33 & 32 & 4 & 100 & 0.157 & 0.628 & 0.012 & 8.71 & 0.03 \\
\hline Crotalaria retusa $\mathrm{L}$. & 6 & 9 & 2 & 0 & 17 & 0.027 & 0.178 & 0.012 & 8.44 & 0.04 \\
\hline Cissus lelyi Hutch. & 9 & 10 & 4 & 0 & 23 & 0.036 & 0.225 & 0.012 & 8.07 & 0.04 \\
\hline Diheteropogon hagerupii Hitchc. & 23 & 39 & 50 & 24 & 136 & 0.214 & 0.749 & 0.011 & 9.6 & 0.02 \\
\hline Digitaria debilis (Desf.) Willd. & 35 & 47 & 35 & 8 & 125 & 0.197 & 0.716 & 0.011 & 9.37 & 0.02 \\
\hline Spermacoce radiata (DC.) Hiern. & 49 & 65 & 48 & 16 & 178 & 0.28 & 0.856 & 0.011 & 9.37 & 0.03 \\
\hline Lantana rhodesiensis Moldenke & 15 & 16 & 6 & 3 & 40 & 0.063 & 0.339 & 0.011 & 9.08 & 0.03 \\
\hline Tephrosia pedicellata Bak & 39 & 39 & 47 & 7 & 132 & 0.208 & 0.737 & 0.011 & 8.23 & 0.04 \\
\hline Azadirachta indica A. Juss. & 10 & 3 & 3 & 1 & 17 & 0.027 & 0.178 & 0.01 & 10.5 & 0.02 \\
\hline Asparagus africanus Lam. & 3 & 6 & 11 & 8 & 28 & 0.044 & 0.261 & 0.01 & 9.79 & 0.02 \\
\hline Evolvulus alsinoides (L.) L. & 24 & 17 & 13 & 5 & 59 & 0.093 & 0.446 & 0.01 & 9.31 & 0.03 \\
\hline Spermacoce stachydea DC. & 64 & 84 & 66 & 24 & 238 & 0.375 & 0.954 & 0.01 & 9.2 & 0.03 \\
\hline Paspalum scrobiculatum L. & 26 & 20 & 16 & 5 & 67 & 0.106 & 0.486 & 0.01 & 8.78 & 0.03 \\
\hline $\begin{array}{l}\text { Euclasta condylotricha (Steud.) } \\
\text { Stapf. }\end{array}$ & 22 & 12 & 21 & 3 & 58 & 0.091 & 0.441 & 0.01 & 8.66 & 0.03 \\
\hline Baissea multiflora A. DC. & 6 & 5 & 17 & 7 & 35 & 0.055 & 0.308 & 0.01 & 8.45 & 0.04 \\
\hline Microchloa indica (L.f.) P. Beauv. & 59 & 73 & 57 & 21 & 210 & 0.331 & 0.916 & 0.01 & 8.37 & 0.04 \\
\hline Cissus populnea Guill. \& Perr. & 28 & 17 & 38 & 14 & 97 & 0.153 & 0.617 & 0.01 & 8.05 & 0.04 \\
\hline Raphionacme daronii Berhaut & 1 & 5 & 10 & 5 & 21 & 0.033 & 0.21 & 0.01 & 7.62 & 0.05 \\
\hline Schwenckia americana L. & 7 & 6 & 2 & 0 & 15 & 0.024 & 0.161 & 0.01 & 7.05 & 0.07 \\
\hline $\begin{array}{l}\text { Species not statistically } \\
\text { significantly linked with fire units }\end{array}$ & & & & & & & & & & \\
\hline $\begin{array}{l}\text { Stylosanthes fruticosa } \\
\text { Alston }\end{array}$ & 14 & 10 & 8 & 1 & 33 & 0.052 & 0.295 & 0.009 & 7.33 & 0.06 \\
\hline Tamarindus indica L. & 18 & 8 & 20 & 9 & 55 & 0.087 & 0.425 & 0.009 & 7 & 0.07 \\
\hline Eriospermum abyssinicum Baker & 16 & 12 & 12 & 1 & 41 & 0.065 & 0.345 & 0.009 & 6.96 & 0.07 \\
\hline Hoslundia opposita Vahl. & 5 & 1 & 10 & 2 & 18 & 0.028 & 0.186 & 0.009 & 6.57 & 0.09 \\
\hline $\begin{array}{l}\text { Sporobolus festivus Hochst. ex A. } \\
\text { Rich. }\end{array}$ & 46 & 55 & 43 & 14 & 158 & 0.249 & 0.809 & 0.008 & 7.29 & 0.06 \\
\hline Acacia dudgeoni Craib ex Hall & 27 & 42 & 58 & 22 & 149 & 0.235 & 0.786 & 0.008 & 7.12 & 0.07 \\
\hline Strychnos spinosa Lam. & 18 & 32 & 32 & 19 & 101 & 0.159 & 0.632 & 0.008 & 6.99 & 0.07 \\
\hline $\begin{array}{l}\text { Pandiaka angustifolia } \quad \text { (Vahl) } \\
\text { Hepper }\end{array}$ & 36 & 51 & 62 & 30 & 179 & 0.282 & 0.858 & 0.008 & 6.95 & 0.07 \\
\hline $\begin{array}{l}\text { Holarrhena floribunda (G. Don) } \\
\text { Dur. \& Schinz }\end{array}$ & 9 & 2 & 6 & 4 & 21 & 0.033 & 0.21 & 0.008 & 6.58 & 0.09 \\
\hline $\begin{array}{l}\text { Maytenus senegalensis (Lam.) } \\
\text { Exell. }\end{array}$ & 45 & 41 & 43 & 11 & 140 & 0.22 & 0.761 & 0.008 & 6.57 & 0.09 \\
\hline $\begin{array}{l}\text { Cymbopogon giganteus Chiov. var } \\
\text { giganteus }\end{array}$ & 7 & 9 & 2 & 3 & 21 & 0.033 & 0.21 & 0.008 & 5.54 & 0.13 \\
\hline $\begin{array}{l}\text { Ampelocissus grantii } \\
\text { Planch. }\end{array}$ & 18 & 10 & 11 & 4 & 43 & 0.068 & 0.357 & 0.007 & 6.8 & 0.08 \\
\hline Hymenocardia acida Tul. & 22 & 19 & 15 & 4 & 60 & 0.094 & 0.451 & 0.007 & 6.52 & 0.09 \\
\hline
\end{tabular}




\begin{tabular}{|c|c|c|c|c|c|c|c|c|c|c|}
\hline \multirow[t]{2}{*}{ Species name } & \multicolumn{4}{|c|}{ Fire regime } & \multirow[b]{2}{*}{ Total } & \multirow[b]{2}{*}{ Freq. } & \multirow[b]{2}{*}{ Entropy } & \multirow[b]{2}{*}{ MI } & \multirow[b]{2}{*}{$\mathrm{Khi}^{2}$} & \multirow[b]{2}{*}{ Proba } \\
\hline & $\begin{array}{l}\text { No } \\
\text { fire }\end{array}$ & $\begin{array}{l}\text { Infrequen } \\
\text { fires }\end{array}$ & $\begin{array}{l}\text { Fairly } \\
\text { frequent } \\
\text { fires }\end{array}$ & $\begin{array}{l}\text { Yearly or } \\
\text { biennal } \\
\text { fires }\end{array}$ & & & & & & \\
\hline $\begin{array}{l}\text { Brachiaria distichophylla (Trin.) } \\
\text { Stapf. }\end{array}$ & 45 & 63 & 51 & 16 & 175 & 0.276 & 0.849 & 0.007 & 6.34 & 0.09 \\
\hline Indigofera dendroides Jacq & 28 & 51 & 53 & 14 & 146 & 0.23 & 0.778 & 0.007 & 6.32 & 0.10 \\
\hline $\begin{array}{l}\text { Hackelochloa granularis } \\
\text { Ktze }\end{array}$ & 29 & 53 & 45 & 14 & 141 & 0.222 & 0.764 & 0.007 & 6.32 & 0.10 \\
\hline $\begin{array}{l}\text { Sclerocarya birrea } \\
\text { Hochst. }\end{array}$ & 37 & 38 & 31 & 10 & 116 & 0.183 & 0.686 & 0.007 & 6.21 & 0.10 \\
\hline $\begin{array}{l}\text { Xeroderris stühlmannii } \quad \text { (Taub.) } \\
\text { Mendonça \& E.P. Sousa }\end{array}$ & 10 & 12 & 25 & 9 & 56 & 0.088 & 0.43 & 0.007 & 5.99 & 0.11 \\
\hline Annona senegalensis Pers. & 71 & 81 & 76 & 24 & 252 & 0.397 & 0.969 & 0.007 & 5.93 & 0.11 \\
\hline Pteleopsis suberosa Engl. \& Diels. & 43 & 58 & 53 & 13 & 167 & 0.263 & 0.831 & 0.007 & 5.87 & 0.12 \\
\hline Tacca leontopetaloides (L.) O Ktze & 30 & 27 & 24 & 7 & 88 & 0.139 & 0.581 & 0.007 & 5.79 & 0.12 \\
\hline $\begin{array}{l}\text { Crotalaria cephalotes Steud ex A } \\
\text { Rich }\end{array}$ & 12 & 12 & 8 & 1 & 33 & 0.052 & 0.295 & 0.007 & 5.48 & 0.14 \\
\hline Senna singueana (Del.) Lock & 19 & 22 & 18 & 3 & 62 & 0.098 & 0.461 & 0.007 & 5.03 & 0.17 \\
\hline Cyperus esculentus L. & 7 & 5 & 5 & 0 & 17 & 0.027 & 0.178 & 0.007 & 3.98 & 0.26 \\
\hline Dioscorea dumetorum (Kunth) Pax & 22 & 12 & 20 & 6 & 60 & 0.094 & 0.451 & 0.006 & 5.81 & 0.12 \\
\hline $\begin{array}{l}\text { Wissadula amplissima (L.) R.E. } \\
\text { Fries }\end{array}$ & 22 & 31 & 20 & 7 & 80 & 0.126 & 0.546 & 0.006 & 5.45 & 0.14 \\
\hline $\begin{array}{l}\text { Pericopsis } \quad \text { laxiflora } \\
\text { Meeuwen }\end{array}$ & 19 & 18 & 33 & 14 & 84 & 0.132 & 0.564 & 0.006 & 5.15 & 0.16 \\
\hline Andropogon pseudapricus Stapf. & 42 & 61 & 78 & 25 & 206 & 0.324 & 0.909 & 0.006 & 5.07 & 0.17 \\
\hline Sida alba L. & 25 & 24 & 18 & 12 & 79 & 0.124 & 0.542 & 0.006 & 4.94 & 0.17 \\
\hline $\begin{array}{l}\text { Crotalaria senegalensis (Pers) } \\
\text { Bacle ex DC }\end{array}$ & 10 & 13 & 8 & 1 & 32 & 0.05 & 0.288 & 0.006 & 4.81 & 0.18 \\
\hline Dioscorea togoensis Knuth & 12 & 6 & 14 & 7 & 39 & 0.061 & 0.333 & 0.006 & 4.55 & 0.21 \\
\hline Kyllinga erecta Schumach. & 7 & 2 & 8 & 4 & 21 & 0.033 & 0.21 & 0.006 & 4.52 & 0.21 \\
\hline Grewia bicolor Juss. & 9 & 4 & 13 & 5 & 31 & 0.049 & 0.281 & 0.006 & 4.46 & 0.21 \\
\hline Albizia chevalieri Harms & 10 & 10 & 16 & 1 & 37 & 0.058 & 0.321 & 0.006 & 4.35 & 0.23 \\
\hline Vitex simplicifolia Oliv. & 20 & 14 & 14 & 5 & 53 & 0.083 & 0.414 & 0.005 & 4.93 & 0.18 \\
\hline Polygala arenaria Willd. & 5 & 7 & 5 & 6 & 23 & 0.036 & 0.225 & 0.005 & 4.73 & 0.19 \\
\hline $\begin{array}{l}\text { Euphorbia convolvuloides Hochst } \\
\text { ex Benth }\end{array}$ & 4 & 8 & 6 & 6 & 24 & 0.038 & 0.232 & 0.005 & 4.6 & 0.20 \\
\hline Vicoa leptoclada (Webb) Dandy & 4 & 8 & 6 & 6 & 24 & 0.038 & 0.232 & 0.005 & 4.6 & 0.20 \\
\hline $\begin{array}{l}\text { Khaya senegalensis (Desr.) A. } \\
\text { Juss. }\end{array}$ & 14 & 13 & 8 & 7 & 42 & 0.066 & 0.351 & 0.005 & 4.54 & 0.21 \\
\hline Isoberlinia doka Craib \& Stapf & 10 & 14 & 18 & 11 & 53 & 0.083 & 0.414 & 0.005 & 4.52 & 0.21 \\
\hline Sterculia setigera Del. & 14 & 16 & 30 & 8 & 68 & 0.107 & 0.491 & 0.005 & 4.51 & 0.21 \\
\hline Hibiscus asper Hook. f. & 20 & 34 & 24 & 9 & 87 & 0.137 & 0.576 & 0.005 & 4.43 & 0.22 \\
\hline $\begin{array}{l}\text { Diheteropogon amplectens (Nees) } \\
\text { W. D. Clayton }\end{array}$ & 7 & 7 & 17 & 4 & 35 & 0.055 & 0.308 & 0.005 & 4.33 & 0.23 \\
\hline Acacia sieberiana DC. & 11 & 22 & 28 & 9 & 70 & 0.11 & 0.501 & 0.005 & 4.12 & 0.25 \\
\hline $\begin{array}{l}\text { Brachiaria lata (Schumach.) C.E. } \\
\text { Hubbard }\end{array}$ & 3 & 11 & 9 & 2 & 25 & 0.039 & 0.239 & 0.005 & 4.08 & 0.25 \\
\hline $\begin{array}{l}\text { Indigofera trichopoda Lepr. ex } \\
\text { Guill. \& Perr. }\end{array}$ & 20 & 34 & 32 & 17 & 103 & 0.162 & 0.64 & 0.005 & 4.02 & 0.26 \\
\hline $\begin{array}{l}\text { Parinari curatellifolia Planch. ex } \\
\text { Benth. }\end{array}$ & 18 & 19 & 13 & 5 & 55 & 0.087 & 0.425 & 0.005 & 3.93 & 0.27 \\
\hline Tephrosia linearis Pers. & 6 & 12 & 11 & 1 & 30 & 0.047 & 0.275 & 0.005 & 3.67 & 0.30 \\
\hline Fimbristylis ovata (Burm. f.) Kern & 2 & 9 & 7 & 2 & 20 & 0.031 & 0.202 & 0.005 & 3.66 & 0.30 \\
\hline Boswellia dalzielii Hutch. & 2 & 8 & 9 & 4 & 23 & 0.036 & 0.225 & 0.005 & 3.58 & 0.31 \\
\hline Capparis sepiaria L. & 8 & 4 & 11 & 5 & 28 & 0.044 & 0.261 & 0.005 & 3.56 & 0.31 \\
\hline Gardenia sokotensis Hutch. & 5 & 6 & 5 & 0 & 16 & 0.025 & 0.17 & 0.005 & 2.61 & 0.46 \\
\hline $\begin{array}{l}\text { Brachiaria jubata (Fig. \& De Not) } \\
\text { Stapf }\end{array}$ & 4 & 9 & 7 & 6 & 26 & 0.041 & 0.247 & 0.004 & 4.13 & 0.25 \\
\hline Biophytum petersianum Klotzsch. & 7 & 16 & 9 & 5 & 37 & 0.058 & 0.321 & 0.004 & 4.01 & 0.26 \\
\hline Dioscorea bulbifera L. & 10 & 5 & 6 & 4 & 25 & 0.039 & 0.239 & 0.004 & 4 & 0.26 \\
\hline $\begin{array}{llll}\text { Loudetia } & \text { simplex (Nees) } & \text { C.E. } \\
\text { Hubbard } & & & \end{array}$ & 7 & 7 & 14 & 7 & 35 & 0.055 & 0.308 & 0.004 & 3.91 & 0.27 \\
\hline
\end{tabular}




\begin{tabular}{|c|c|c|c|c|c|c|c|c|c|c|}
\hline \multirow[t]{2}{*}{ Species name } & \multicolumn{4}{|c|}{ Fire regime } & \multirow[b]{2}{*}{ Total } & \multirow[b]{2}{*}{ Freq. } & \multirow[b]{2}{*}{ Entropy } & \multirow[b]{2}{*}{ MI } & \multirow[b]{2}{*}{$\mathrm{Khi}^{2}$} & \multirow[b]{2}{*}{ Proba } \\
\hline & $\begin{array}{l}\text { No } \\
\text { fire }\end{array}$ & $\begin{array}{l}\text { Infrequen } \\
\text { fires }\end{array}$ & $\begin{array}{l}\text { Fairly } \\
\text { frequent } \\
\text { fires }\end{array}$ & $\begin{array}{c}\text { Yearly or } \\
\text { biennal } \\
\text { fires }\end{array}$ & & & & & & \\
\hline Vitellaria paradoxa C.F. Gaernt. & 95 & 113 & 111 & 39 & 358 & 0.564 & 0.988 & 0.004 & 3.84 & 0.28 \\
\hline $\begin{array}{l}\text { Gardenia ternifolia Schumach. \& } \\
\text { Thonn. }\end{array}$ & 40 & 39 & 35 & 16 & 130 & 0.205 & 0.731 & 0.004 & 3.81 & 0.28 \\
\hline Combretum fragrans F. Hoffm. & 20 & 15 & 22 & 12 & 69 & 0.109 & 0.496 & 0.004 & 3.73 & 0.29 \\
\hline Combretum molle R. Br. ex G. Don & 17 & 24 & 25 & 15 & 81 & 0.128 & 0.551 & 0.004 & 3.71 & 0.29 \\
\hline Strychnos innocua Del. & 5 & 12 & 7 & 2 & 26 & 0.041 & 0.247 & 0.004 & 3.65 & 0.30 \\
\hline Lannea acida A. Rich. & 58 & 77 & 69 & 33 & 237 & 0.373 & 0.953 & 0.004 & 3.63 & 0.30 \\
\hline $\begin{array}{l}\text { Saba senegalensis (A. DC.) } \\
\text { Pichon. }\end{array}$ & 23 & 15 & 23 & 9 & 70 & 0.11 & 0.501 & 0.004 & 3.63 & 0.30 \\
\hline Aspilia kotschyi (Sch. Bip.) Oliv. & 20 & 15 & 29 & 9 & 73 & 0.115 & 0.515 & 0.004 & 3.61 & 0.31 \\
\hline $\begin{array}{l}\text { Sarcocephalus latifolius (Smith) } \\
\text { Bruce }\end{array}$ & 8 & 13 & 8 & 7 & 36 & 0.057 & 0.314 & 0.004 & 3.6 & 0.31 \\
\hline $\begin{array}{l}\text { Loudetia togoensis (Pilger) C.E. } \\
\text { Hubbard }\end{array}$ & 63 & 67 & 75 & 21 & 226 & 0.356 & 0.939 & 0.004 & 3.56 & 0.31 \\
\hline $\begin{array}{l}\text { Chasmopodium caudatum (Hack) } \\
\text { Stapf }\end{array}$ & 5 & 14 & 12 & 6 & 37 & 0.058 & 0.321 & 0.004 & 3.53 & 0.32 \\
\hline Euphorbia hirta L & 3 & 3 & 7 & 4 & 17 & 0.027 & 0.178 & 0.004 & 3.4 & 0.33 \\
\hline Securidaca longepedunculata Fres. & 15 & 20 & 17 & 3 & 55 & 0.087 & 0.425 & 0.004 & 3.39 & 0.34 \\
\hline $\begin{array}{l}\text { Schizachyrium platyphyllum } \\
\text { (Franch.) Stapf }\end{array}$ & 8 & 10 & 5 & 2 & 25 & 0.039 & 0.239 & 0.004 & 3.13 & 0.37 \\
\hline Cassia mimosoides L. & 46 & 53 & 47 & 24 & 170 & 0.268 & 0.838 & 0.004 & 3.1 & 0.38 \\
\hline Mitragyna inermis (Wild) Kuntze & 15 & 17 & 11 & 5 & 48 & 0.076 & 0.386 & 0.004 & 3.07 & 0.38 \\
\hline Acacia seyal Del. & 7 & 16 & 16 & 4 & 43 & 0.068 & 0.357 & 0.004 & 2.95 & 0.40 \\
\hline Leptadenia hastata (Pers) Decne & 4 & 11 & 12 & 3 & 30 & 0.047 & 0.275 & 0.004 & 2.9 & 0.41 \\
\hline Zornia glochidiata Reichb ex DC & 9 & 8 & 7 & 1 & 25 & 0.039 & 0.239 & 0.004 & 2.9 & 0.41 \\
\hline $\begin{array}{l}\text { Monocymbium ceresiiforme (Nees) } \\
\text { Stapf }\end{array}$ & 4 & 10 & 13 & 4 & 31 & 0.049 & 0.281 & 0.004 & 2.85 & 0.42 \\
\hline $\begin{array}{l}\text { Brachiaria xantholeuca (Hack. ex } \\
\text { Schinz) Stapf }\end{array}$ & 5 & 8 & 11 & 1 & 25 & 0.039 & 0.239 & 0.004 & 2.75 & 0.43 \\
\hline Mitracarpus scaber Zucc & 3 & 8 & 5 & 4 & 20 & 0.031 & 0.202 & 0.003 & 3 & 0.39 \\
\hline Andropogon fastigiatus Sw & 46 & 67 & 61 & 27 & 201 & 0.317 & 0.901 & 0.003 & 2.91 & 0.41 \\
\hline Cyanotis longifolia Benth. & 11 & 12 & 10 & 8 & 41 & 0.065 & 0.345 & 0.003 & 2.88 & 0.41 \\
\hline Lannea velutina A. Rich. & 35 & 29 & 37 & 12 & 113 & 0.178 & 0.676 & 0.003 & 2.85 & 0.42 \\
\hline Pennisetum pedicellatum Trin. & 69 & 78 & 84 & 25 & 256 & 0.403 & 0.973 & 0.003 & 2.85 & 0.42 \\
\hline Feretia apodanthera Del. & 34 & 41 & 37 & 11 & 123 & 0.194 & 0.709 & 0.003 & 2.84 & 0.42 \\
\hline $\begin{array}{l}\text { Andropogon chinensis (Nees) } \\
\text { Merr. }\end{array}$ & 53 & 71 & 82 & 34 & 240 & 0.378 & 0.957 & 0.003 & 2.78 & 0.43 \\
\hline $\begin{array}{l}\text { Vitex chrysocarpa Planch. ex } \\
\text { Benth. }\end{array}$ & 7 & 3 & 8 & 2 & 20 & 0.031 & 0.202 & 0.003 & 2.68 & 0.45 \\
\hline Cissus gracilis Guill. \& Perr. & 12 & 14 & 10 & 3 & 39 & 0.061 & 0.333 & 0.003 & 2.45 & 0.49 \\
\hline $\begin{array}{l}\text { Detarium microcarpum Guill. \& } \\
\text { Perr. }\end{array}$ & 51 & 75 & 77 & 29 & 232 & 0.365 & 0.947 & 0.003 & 2.44 & 0.49 \\
\hline Elionurus elegans Kunth & 36 & 48 & 41 & 15 & 140 & 0.22 & 0.761 & 0.003 & 2.43 & 0.49 \\
\hline Sida rhombifolia L. & 8 & 5 & 5 & 2 & 20 & 0.031 & 0.202 & 0.003 & 2.42 & 0.49 \\
\hline $\begin{array}{l}\text { Combretum glutinosum Perr. ex } \\
\text { DC. }\end{array}$ & 37 & 49 & 63 & 20 & 169 & 0.266 & 0.836 & 0.003 & 2.4 & 0.50 \\
\hline Sporobolus pyramidalis P. Beauv & 18 & 13 & 16 & 7 & 54 & 0.085 & 0.42 & 0.003 & 2.38 & 0.50 \\
\hline Excoecaria grahamii Stapf & 22 & 25 & 23 & 6 & 76 & 0.12 & 0.528 & 0.003 & 2.34 & 0.51 \\
\hline Fimbristylis ferruginea (L.) Vahl & 3 & 7 & 8 & 1 & 19 & 0.03 & 0.194 & 0.003 & 2.32 & 0.51 \\
\hline $\begin{array}{l}\text { Lannea microcarpa Engl. \& K. } \\
\text { Krause }\end{array}$ & 39 & 40 & 55 & 15 & 149 & 0.235 & 0.786 & 0.003 & 2.3 & 0.52 \\
\hline $\begin{array}{l}\text { Dichrostachys cinerea (L.) Wight \& } \\
\text { Arn. }\end{array}$ & 44 & 42 & 44 & 18 & 148 & 0.233 & 0.783 & 0.003 & 2.27 & 0.52 \\
\hline $\begin{array}{l}\text { Dioscorea abyssinica Hochst. ex } \\
\text { Kunth }\end{array}$ & 20 & 20 & 20 & 5 & 65 & 0.102 & 0.476 & 0.003 & 2.27 & 0.52 \\
\hline Terminalia laxiflora Engl. & 58 & 70 & 76 & 22 & 226 & 0.356 & 0.939 & 0.003 & 2.16 & 0.54 \\
\hline $\begin{array}{l}\text { Schizachyrium rupestre } \\
\text { Schum.) Stapf }\end{array}$ & 4 & 7 & 9 & 1 & 21 & 0.033 & 0.21 & 0.003 & 2.08 & 0.56 \\
\hline Schizachyrium exile (Hochst.) & 28 & 39 & 37 & 19 & 123 & 0.194 & 0.709 & 0.002 & 2.2 & 0.54 \\
\hline
\end{tabular}




\begin{tabular}{|c|c|c|c|c|c|c|c|c|c|c|}
\hline \multirow[t]{2}{*}{ Species name } & \multicolumn{4}{|c|}{ Fire regime } & \multirow[b]{2}{*}{ Total } & \multirow{3}{*}{ Freq. } & \multirow[b]{2}{*}{ Entropy } & \multirow[b]{2}{*}{ MI } & \multirow[b]{2}{*}{$\mathrm{Khi}^{2}$} & \multirow[b]{2}{*}{ Proba } \\
\hline & $\begin{array}{l}\text { No } \\
\text { fire }\end{array}$ & $\begin{array}{l}\text { Infrequen } \\
\text { fires }\end{array}$ & $\begin{array}{l}\text { Fairly } \\
\text { frequent } \\
\text { fires }\end{array}$ & $\begin{array}{l}\text { Yearly or } \\
\text { biennal } \\
\text { fires }\end{array}$ & & & & & & \\
\hline \multicolumn{10}{|l|}{ Pilger } & \\
\hline Cassia sieberiana DC. & 34 & 34 & 35 & 11 & 114 & 0.18 & 0.679 & 0.002 & 2.17 & 0.54 \\
\hline Hyptis spicigera Lam. & 11 & 10 & 10 & 7 & 38 & 0.06 & 0.327 & 0.002 & 2.15 & 0.55 \\
\hline Ipomoea eriocarpa R. Br. & 7 & 8 & 8 & 6 & 29 & 0.046 & 0.268 & 0.002 & 2.07 & 0.56 \\
\hline Tephrosia bracteolata Guill. \& Perr. & 24 & 34 & 35 & 9 & 102 & 0.161 & 0.636 & 0.002 & 1.96 & 0.58 \\
\hline Melliniella micrantha Harms & 11 & 7 & 13 & 4 & 35 & 0.055 & 0.308 & 0.002 & 1.95 & 0.59 \\
\hline $\begin{array}{l}\text { Dactyloctenium aegyptium (L.) } \\
\text { Willd. }\end{array}$ & 7 & 14 & 15 & 4 & 40 & 0.063 & 0.339 & 0.002 & 1.88 & 0.60 \\
\hline $\begin{array}{l}\text { Piliostigma reticulatum } \quad \text { (DC.) } \\
\text { Hochst. }\end{array}$ & 15 & 18 & 13 & 7 & 53 & 0.083 & 0.414 & 0.002 & 1.87 & 0.60 \\
\hline Grewia lasiodiscus K. Schum. & 31 & 35 & 49 & 15 & 130 & 0.205 & 0.731 & 0.002 & 1.72 & 0.64 \\
\hline $\begin{array}{l}\text { Setaria pallide-fusca (Schumach.) } \\
\text { Stapf \& C.E. Hubbard }\end{array}$ & 38 & 42 & 44 & 13 & 137 & 0.216 & 0.752 & 0.002 & 1.66 & 0.65 \\
\hline Leucas martinicensis (Jacq.) R. Br. & 7 & 4 & 6 & 3 & 20 & 0.031 & 0.202 & 0.002 & 1.61 & 0.66 \\
\hline $\begin{array}{l}\text { Loudetia hordeiformis (Stapf) } \\
\text { C.E.Hubbard }\end{array}$ & 5 & 8 & 8 & 1 & 22 & 0.035 & 0.217 & 0.002 & 1.6 & 0.66 \\
\hline Parkia biglobosa (Jacq.) Benth. & 39 & 38 & 42 & 19 & 138 & 0.217 & 0.755 & 0.002 & 1.56 & 0.67 \\
\hline Daniellia oliveri (R.) Hutch. \& Dalz. & 35 & 40 & 42 & 12 & 129 & 0.203 & 0.728 & 0.002 & 1.53 & 0.68 \\
\hline $\begin{array}{l}\text { Tripogon minimus (A. Rich.) } \\
\text { Hochst. ex Steud. }\end{array}$ & 20 & 30 & 30 & 14 & 94 & 0.148 & 0.605 & 0.002 & 1.52 & 0.68 \\
\hline $\begin{array}{l}\text { Digitaria gayana (Kunth.) Stapf ex } \\
\text { A. Cheval. }\end{array}$ & 6 & 8 & 8 & 1 & 23 & 0.036 & 0.225 & 0.002 & 1.47 & 0.69 \\
\hline $\begin{array}{l}\text { Piliostigma thonningii (Schumm.) } \\
\text { Milne-Redhead. }\end{array}$ & 74 & 88 & 87 & 33 & 282 & 0.444 & 0.991 & 0.002 & 1.45 & 0.70 \\
\hline $\begin{array}{l}\text { Crossopteryx febrifuga (Afzel. ex } \\
\text { G. Don.) Benth. }\end{array}$ & 41 & 55 & 65 & 24 & 185 & 0.291 & 0.87 & 0.002 & 1.45 & 0.70 \\
\hline $\begin{array}{l}\text { Acacia macrostachya Reichenb. ex } \\
\text { DC }\end{array}$ & 44 & 57 & 64 & 19 & 184 & 0.29 & 0.868 & 0.002 & 1.42 & 0.71 \\
\hline Crinum zeylanicum auct. & 6 & 6 & 5 & 1 & 18 & 0.028 & 0.186 & 0.002 & 1.4 & 0.71 \\
\hline Cassia nigricans Vahl & 7 & 11 & 10 & 2 & 30 & 0.047 & 0.275 & 0.002 & 1.38 & 0.71 \\
\hline Melochia corchorifolia L. & 3 & 7 & 8 & 3 & 21 & 0.033 & 0.21 & 0.002 & 1.38 & 0.72 \\
\hline Bridelia ferruginea Benth. & 21 & 19 & 20 & 9 & 69 & 0.109 & 0.496 & 0.002 & 1.35 & 0.72 \\
\hline Ximenia americana L. & 21 & 29 & 30 & 8 & 88 & 0.139 & 0.581 & 0.002 & 1.35 & 0.72 \\
\hline Ctenium elegans Kunth & 4 & 8 & 9 & 2 & 23 & 0.036 & 0.225 & 0.002 & 1.32 & 0.73 \\
\hline Triumfetta pentandra A. Rich. & 9 & 7 & 9 & 5 & 30 & 0.047 & 0.275 & 0.001 & 1.28 & 0.74 \\
\hline Stylochiton warneckei Engl. & 32 & 34 & 38 & 11 & 115 & 0.181 & 0.682 & 0.001 & 1.23 & 0.75 \\
\hline $\begin{array}{l}\text { Combretum nigricans Lepr. ex } \\
\text { Guill. \& Perr. }\end{array}$ & 35 & 37 & 38 & 13 & 123 & 0.194 & 0.709 & 0.001 & 1.21 & 0.75 \\
\hline $\begin{array}{ll}\text { Siphonochilus } & \text { aethiopicus } \\
\text { (Schweinf.) B.L.Burtt }\end{array}$ & 38 & 37 & 41 & 17 & 133 & 0.209 & 0.74 & 0.001 & 1.2 & 0.76 \\
\hline Acacia ataxacantha DC. & 11 & 11 & 12 & 7 & 41 & 0.065 & 0.345 & 0.001 & 1.16 & 0.77 \\
\hline Andropogon gayanus Kunth & 52 & 69 & 69 & 29 & 219 & 0.345 & 0.929 & 0.001 & 1.14 & 0.77 \\
\hline $\begin{array}{l}\text { Anogeissus leiocarpus (DC.) Guill. } \\
\text { \& Perr. }\end{array}$ & 41 & 55 & 55 & 24 & 175 & 0.276 & 0.849 & 0.001 & 1.14 & 0.77 \\
\hline Fimbristylis hispidula (Vahl) Kunth. & 37 & 44 & 42 & 15 & 138 & 0.217 & 0.496 & 0.002 & 0.95 & 0.78 \\
\hline Trichilia emetica Vahl & 7 & 9 & 6 & 3 & 25 & 0.039 & 0.239 & 0.001 & 1.07 & 0.79 \\
\hline $\begin{array}{l}\text { Flueggea virosa (Roxb. Ex Willd.) } \\
\text { Voigt }\end{array}$ & 48 & 51 & 55 & 19 & 173 & 0.272 & 0.845 & 0.001 & 1.03 & 0.80 \\
\hline Striga hermonthica Benth. & 6 & 11 & 10 & 3 & 30 & 0.047 & 0.275 & 0.001 & 1 & 0.80 \\
\hline Grewia venusta Fresen. & 11 & 10 & 12 & 3 & 36 & 0.057 & 0.314 & 0.001 & 0.96 & 0.81 \\
\hline Lepidagathis anobrya Nees & 24 & 25 & 32 & 9 & 90 & 0.142 & 0.589 & 0.001 & 0.88 & 0.83 \\
\hline $\begin{array}{l}\text { Hexalobus monopetalus (A. Rich.) } \\
\text { Engl. \& Diels }\end{array}$ & 8 & 11 & 14 & 6 & 39 & 0.061 & 0.333 & 0.001 & 0.83 & 0.84 \\
\hline Balanites aegyptiaca (L.) Del. & 14 & 22 & 22 & 8 & 66 & 0.104 & 0.481 & 0.001 & 0.82 & 0.85 \\
\hline Cassia tora L. & 6 & 9 & 12 & 4 & 31 & 0.049 & 0.281 & 0.001 & 0.79 & 0.85 \\
\hline $\begin{array}{l}\text { Cyphostemma waterlotii (A. Chev.) } \\
\text { Descoings }\end{array}$ & 3 & 5 & 7 & 2 & 17 & 0.027 & 0.178 & 0.001 & 0.76 & 0.86 \\
\hline Schoenefeldia gracilis Kunth & 6 & 10 & 11 & 3 & 30 & 0.047 & 0.275 & 0.001 & 0.75 & 0.86 \\
\hline
\end{tabular}




\begin{tabular}{|c|c|c|c|c|c|c|c|c|c|c|}
\hline \multirow[t]{2}{*}{ Species name } & \multicolumn{4}{|c|}{ Fire regime } & \multirow[b]{2}{*}{ Total } & \multirow[b]{2}{*}{ Freq. } & \multirow[b]{2}{*}{ Entropy } & \multirow[b]{2}{*}{ MI } & \multirow[b]{2}{*}{$\mathrm{Khi}^{2}$} & \multirow[b]{2}{*}{ Proba } \\
\hline & $\begin{array}{l}\text { No } \\
\text { fire }\end{array}$ & $\begin{array}{l}\text { Infrequen } \\
\text { fires }\end{array}$ & $\begin{array}{l}\text { Fairly } \\
\text { frequent } \\
\text { fires }\end{array}$ & $\begin{array}{l}\text { Yearly or } \\
\text { biennal } \\
\text { fires }\end{array}$ & & & & & & \\
\hline Combretum micranthum G. Don & 15 & 13 & 17 & 6 & 51 & 0.08 & 0.403 & 0.001 & 0.72 & 0.87 \\
\hline $\begin{array}{l}\text { Lepidagathis collina (Endl.) Milne- } \\
\text { Redhead }\end{array}$ & 10 & 13 & 14 & 7 & 44 & 0.069 & 0.363 & 0.001 & 0.64 & 0.89 \\
\hline Swartzia madagascariensis Desv. & 9 & 13 & 11 & 4 & 37 & 0.058 & 0.321 & 0.001 & 0.61 & 0.89 \\
\hline Cyanotis lanata Benth. & 14 & 18 & 23 & 8 & 63 & 0.099 & 0.466 & 0.001 & 0.56 & 0.91 \\
\hline Mollugo nudicaulis Lam. & 4 & 4 & 5 & 1 & 14 & 0.022 & 0.153 & 0.001 & 0.41 & 0.93 \\
\hline Hyparrhenia subplumosa Stapf & 7 & 6 & 7 & 3 & 23 & 0.036 & 0.225 & 0 & 0.42 & 0.93 \\
\hline Combretum collinum Fresen & 41 & 43 & 51 & 18 & 153 & 0.241 & 0.797 & 0 & 0.41 & 0.93 \\
\hline Terminalia macroptera G. \& Perr. & 14 & 19 & 22 & 7 & 62 & 0.098 & 0.461 & 0 & 0.4 & 0.94 \\
\hline $\begin{array}{l}\text { Alysicarpus ovalifolius (Schum. \& } \\
\text { Thonn.) Léonard }\end{array}$ & 9 & 12 & 14 & 4 & 39 & 0.061 & 0.333 & 0 & 0.34 & 0.95 \\
\hline $\begin{array}{l}\text { Stereospermum } \\
\text { Cham. }\end{array}$ & 22 & 24 & 28 & 9 & 83 & 0.131 & 0.559 & 0 & 0.26 & 0.96 \\
\hline Digitaria horizontalis Willd. & 4 & 4 & 5 & 2 & 15 & 0.024 & 0.161 & 0 & 0.07 & 0.99 \\
\hline Total number of relevés & 160 & 188 & 209 & 78 & 635 & & & & & \\
\hline
\end{tabular}

